Effect of Mo incorporation on electrocatalytic performance of Ti-Mo mixed oxidecarbon composite supported Pt electrocatalysts

Reaction Kinetics, Mechanisms and Catalysis, Volume 121 (2017) 141-160.

Ádám Vass, Irina Borbáth, Zoltán Pászti, István Bakos, István E. Sajó, Péter Németh, András Tompos

ISSN: 1878-5190; Source Type: Journal; Original language: English; Document Type: Article; Publisher: Springer

Akadémiai Kiadó, Budapest, Hungary 2017

The final publication is available at Springer via

http://dx.doi.org/10.1007/s11144-017-1155-5

Corresponding author: Irina Borbáth

Received: 30 November 2016/Accepted: 4 February 2017/Published online: 15 February 2017

Electronic supplementary material:

The online version of this article (doi: 10.1007/s11144-017-1155-5) contains

supplementary material, which is available to authorized users. 


\title{
Effect of Mo incorporation on electrocatalytic performance of Ti-Mo mixed oxide-carbon composite supported Pt electrocatalysts
}

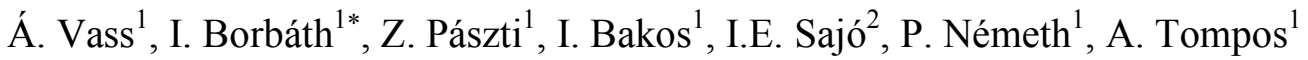 \\ ${ }^{1}$ Institute of Materials and Environmental Chemistry, Research Centre for Natural Sciences, \\ Hungarian Academy of Sciences, H-1117 Budapest, Magyar tudósok körútja 2, Hungary \\ ${ }^{2}$ University of Pécs, Szentágothai Research Centre, Pécs, H-7624, Ifjúság str. 20. Hungary
}

\begin{abstract}
$\mathrm{Ti}_{(1-\mathrm{x})} \mathrm{Mo}_{\mathrm{x}} \mathrm{O}_{2}-\mathrm{C}$ carbon composite supported platinum electocatalysts with systematically varied Ti/Mo ratio were prepared by a multistep sol-gel-based synthesis method. The effect of the composition of the support material on the electrochemical behaviour of the $20 \mathrm{wt} . \% \mathrm{Pt}$ electrocatalysts was investigated and the samples were also characterised by XRD, TEM, EDX and XPS techniques. The composite support ensures enhanced $\mathrm{CO}$ tolerance compared to the reference commercial $20 \mathrm{wt} . \% \mathrm{Pt} / \mathrm{C}$ (Quintech) catalyst. Different Mo species were identified to have critical importance on the electrocatalytic performance both in hydrogen oxidation and CO tolerance. The unincorporated Mo species are not stable upon applying a wide cyclic polarization window and as a consequence they are removed gradually. Higher stability was obtained over Mo species incorporated into the rutile lattice. From the results $\mathrm{Ti} / \mathrm{Mo}=80 / 20$ atomic ratio has been suggested as an optimal composition having the largest ratio of incorporated/non-incorporated Mo species.
\end{abstract}

Keywords Conducting Ti-based mixed oxides, $\mathrm{TiMoO}_{\mathrm{x}}, \mathrm{Composite}$ materials, $\mathrm{Pt}$ electrocatalysts, CO-tolerance

\section{Introduction}

Fuel cells are well positioned to provide an economically compelling solution for "green" electric power generation. For the wide-range implementation of polymer electrolyte membrane fuel cells (PEMFC), it is most essential to produce low-cost durable units. For fuel cells, state of the art systems contain large quantities of platinum supported on carbon black. However, the electrochemical corrosion of carbon [1,2] and concomitant sintering of Pt [3-5] leads to stability problems jeopardizing long term operation of PEMFC stacks. It is therefore important to explore alternative materials that are more stable compared to carbon, i.e. highly corrosion resistant across the anticipated potential $/ \mathrm{pH}$ window experienced in fuel cell electrodes. Titanium dioxide is promising candidate as catalyst support in PEMFC because $\mathrm{TiO}_{2}$ has very good chemical stability in acidic and oxidative environments [6,7]. However, undoped $\mathrm{TiO}_{2}$ oxide is an n-type semiconductor with low electron conductivity and doping with transition metals (e.g., $\mathrm{W}, \mathrm{Nb}$ and Ta) has been used to enhance its electrical conductivity [8-11].

\footnotetext{
${ }^{*}$ Corresponding author, Tel.: +36 1382 6916, email: borbath.irina@ttk.mta.hu, address: H-1519 Budapest, P.O.Box 286, Hungary (Irina Borbáth)
} 
On the other hand, $\mathrm{CO}$ tolerance of the Pt-based catalysts is of high importance when feeding low temperature PEMFC stacks with hydrogen from reformates. It has been demonstrated that by adding oxophilic doping metals such as $\mathrm{W}$ and Mo the CO tolerance of the $\mathrm{Pt} / \mathrm{C}$ electrocatalysts is significantly improved. The second metal is reported to (i) provide the necessary $\mathrm{OH}_{\mathrm{ad}}$ species at less positive potentials than $\mathrm{Pt}$ (according to the "bifunctional mechanism"); (ii) modify the electronic structure of Pt and therefore reduce the adsorption strength of CO (the "electronic effect"); and (iii) to increase catalytic activity as the result of the "hydrogen spillover" effect from Pt to tungsten or molybdenum oxides, leading to formation of bronzes $\left(\mathrm{H}_{\mathrm{x}} \mathrm{MO}_{3}, \mathrm{M}=\mathrm{W}\right.$, Mo) [12-16]. It is well-known [7,17] that $\mathrm{MO}_{3}$ oxides $(\mathrm{M}=\mathrm{W}, \mathrm{Mo})$ can be electrochemically reduced to a non-stoichiometric and electroconductive $\mathrm{H}_{\mathrm{x}} \mathrm{MO}_{3}$.

In agreement with the bifunctional mechanism, the co-catalytic activity is supposed to be due to the good redox properties of the oxides involved. Usually, molybdenum oxides do not exist in a single phase but in mixed-valence oxides $\left(\mathrm{MoO}_{\mathrm{x}}\right)$ [18]. For the Pt-Mo/C system Santiago et al. [19] proposed that the increased CO tolerance is a result of synergism between water gas shift reaction and the bifunctional mechanism.

Recently, the combination of the highly stable $\mathrm{TiO}_{2}$ with $\mathrm{MoO}_{\mathrm{x}}$, was reported to have high electronic conductivity and relative stability in acid solutions. Accordingly, the multifunctional $\mathrm{Ti}_{0.7} \mathrm{Mo}_{0.3} \mathrm{O}_{2}$ support material was successfully applied for Pt-based catalysts for the oxygen reduction reaction (ORR) [20,21].

In our previous studies [22,23] platinum was deposited onto a $\mathrm{Ti}_{0.7} \mathrm{~W}_{0.3} \mathrm{O}_{2}-\mathrm{C}$ composite support in order to stabilize the $\mathrm{Pt}$ nanoparticles and increase the CO-tolerance. Optimum experimental conditions were found to synthesize rutile phase, tungsten-doped $\mathrm{Ti}_{0.7} \mathrm{~W}_{0.3} \mathrm{O}_{2}-\mathrm{C}$ composites by a novel, multistep sol-gel method resulting in exclusive incorporation of $\mathrm{W}$ into $\mathrm{TiO}_{2}$-rutile lattice. Better performance in the $\mathrm{CO}$ electrooxidation for this catalyst compared to the $\mathrm{PtRu} / \mathrm{C}$ benchmark was demonstrated. The electrochemical stability tests revealed that the degradation rate of the $40 \mathrm{wt} . \% \mathrm{Pt} / \mathrm{Ti}_{0.7} \mathrm{~W}_{0.3} \mathrm{O}_{2}-\mathrm{C}$ catalyst is much smaller than that of the commercial $40 \mathrm{wt} \% \mathrm{Pt} / \mathrm{C}$ (Quintech) catalyst.

It is known that less stable transition metal oxides tend to dissolve under acidic conditions and high potentials. Such leaching and subsequent uncontrolled re-deposition of certain components of the electrocatalyst may be detrimental for the performance of the fuel cell, so stability against initial leaching should be checked.

Our aim in this work was to develop a synthesis method for Mo-containing $\mathrm{Ti}_{(1-\mathrm{x})} \mathrm{Mo}_{\mathrm{x}} \mathrm{O}_{2-}$ $\mathrm{C}(\mathrm{x}=0.2-0.4)$ composite supports loaded with $20 \mathrm{wt} . \%$ Pt. Using a combination of structural, spectroscopic and electrochemical methods we assessed the incorporation limit of Mo into the rutile lattice by the proposed synthesis method. The effect of the incorporated and excess molybdenum on the electrocatalytic properties and the short-term stability is also assessed.

\section{Experimental}

Preparation of the $\mathrm{Ti}_{(1-x)} \mathrm{Mo}_{x} \mathrm{O}_{2}-\mathrm{C}$ support materials

Titanium-isopropoxide (Ti(O-i-Pr) $)_{4}$, Aldrich, 97\%) and ammonium heptamolybdate tetrahydrate $\left(\left(\mathrm{NH}_{4}\right)_{6} \mathrm{Mo}_{7} \mathrm{O}_{24} \times 4 \mathrm{H}_{2} \mathrm{O}\right.$, Merck, 99\%) were used as Ti and Mo precursor compounds.

The composite support materials consisting of electroconductive $\mathrm{Ti}_{(1-\mathrm{x})} \mathrm{Mo}_{\mathrm{x}} \mathrm{O}_{2}$ mixed oxide and activated carbon were prepared by using a multistep sol-gel-based synthesis method followed by high-temperature heat treatment, described in detail and demonstrated schematically in Fig. S1 of the Supplementary Material. 
Table 1 reports data on the actual composition and preparation details of the $\mathrm{Ti}_{(1-\mathrm{x})} \mathrm{Mo}_{\mathrm{x}} \mathrm{O}_{2}-\mathrm{C}$ $(x=0.2-0.4)$ composites. The sample identifier contains the intended composition of the $\mathrm{Ti}_{(1-}$ $\left.{ }_{x}\right) \mathrm{Mo}_{\mathrm{x}} \mathrm{O}_{2}$ mixed oxide reflecting the desired Ti/Mo atomic ratio; in all cases the mass ratio of the mixed oxide to the activated carbon was 75:25 (denoted as $\mathrm{Ti}_{(1-\mathrm{x})} \mathrm{M}_{\mathrm{x}} \mathrm{O}_{2}-\mathrm{C}$ ).

Table 1. Nominal composition and preparation details of the samples with the different Ti to Mo ratios.

\begin{tabular}{|c|c|c|c|c|}
\hline Samples $^{\text {a) }}$ & Ti/Mo (at/at) & $\mathrm{Ti}(\mathrm{O}-\mathrm{i}-\mathrm{Pr})_{4}, \mathrm{ml}$ & $1.44 \mathrm{M} \mathrm{HNO}_{3}, \mathrm{ml}$ & $\left(\mathrm{NH}_{4}\right)_{6} \mathrm{Mo}_{7} \mathrm{O}_{24} 4 \mathrm{H}_{2} \mathrm{O}, \mathrm{mg}$ \\
\hline $\mathrm{Ti}_{08} \mathrm{Mo}_{02} \mathrm{O}_{2}-\mathrm{C}$ & $0.8 / 0.2$ & 2.1 & 23.4 & 299 \\
\hline $\mathrm{Ti}_{0.7}{ }^{0.0} \mathrm{Mo}_{0.3} \mathrm{O}_{2}-\mathrm{C}$ & $0.7 / 0.3$ & 1.7 & 19.4 & 426 \\
\hline $\mathrm{Ti}_{0.6} \mathrm{Mo}_{0.4} \mathrm{O}_{2}-\mathrm{C}$ & $0.6 / 0.4$ & 1.4 & 15.8 & 540 \\
\hline
\end{tabular}

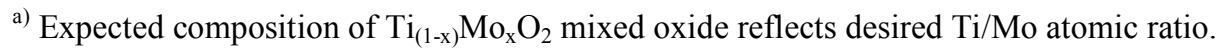

Preparation of the 20 wt.\% Pt/Ti $i_{(1-x)} M_{x} \mathrm{O}_{2}-\mathrm{C}$ electrocatalysts

$\mathrm{Ti}_{(1-\mathrm{x})} \mathrm{Mo}_{\mathrm{x}} \mathrm{O}_{2}-\mathrm{C}$ composite materials were loaded with $20 \mathrm{wt} . \% \mathrm{Pt}$ via a modified $\mathrm{NaBH}_{4}-$ assisted ethylene-glycol (EG) reduction-precipitation method (see Fig. S2 and its description in the Supplementary Material) [22-24].

\section{Physical characterization}

The powder X-ray diffraction (XRD) patterns were obtained in a Philips model PW 3710 based PW 1050 Bragg-Brentano parafocusing goniometer using $\mathrm{CuK}_{\alpha}$ radiation $(\lambda=0.15418$ $\mathrm{nm})$, graphite monochromator and proportional counter. For quantitative analysis silicon powder (NIST SRM 640) was used as internal standard and the scans were evaluated with profile fitting methods. The cell parameters of the crystalline phases were determined from the fitted d-values.

Transmission Electron Microscopy (TEM) studies of the samples were made by use of a FEI Morgagni 268D type transmission electron microscope (accelerating voltage: $100 \mathrm{kV}$, Wfilament). The samples were prepared by grinding in an Achate mortar and dispersing of the resulted powder in ethanol. The average diameter and particles size distribution were calculated by measuring the diameters of no less than 800 randomly selected metal particles in at least ten micrographs of each sample taken from non-aggregated areas.

Energy dispersive X-ray spectrometry (EDX) analysis was carried out with an INCA (Oxford Instruments Ltd.) detector and the INCA Energy software package. EDX analysis of samples was performed by using ZEISS EVO 40XVP scanning electron microscope (accelerating voltage: $20 \mathrm{kV}$, W-filament). At least 5 spatially well separated points have been analyzed in order to get the reported composition values.

X-ray photoelectron spectroscopy (XPS) measurements were carried out using an EA125 electron spectrometer manufactured by OMICRON Nanotechnology GmbH (Germany). The photoelectrons were excited by unmonochromatized $\mathrm{MgK} \alpha(1253.6 \mathrm{eV})$ radiation. Spectra were recorded in the Constant Analyser Energy mode of the energy analyser with $30 \mathrm{eV}$ pass energy resulting in a spectral resolution around $1 \mathrm{eV}$. The powder catalyst samples were suspended in isopropanol then some of this suspension was dried to a standard OMICRON sample plate. Binding energies were referenced to the main component of the $\mathrm{C} 1 \mathrm{~s}$ spectrum of the support (graphite at $284.4 \mathrm{eV}$ binding energy). Data were processed using the CasaXPS software package [25]. Nominal surface compositions were calculated using the XPS MultiQuant software package 
$[26,27]$. Chemical states were identified by XPS databases $[28,29]$ and with the help of the related literature.

\section{Electrochemical characterization}

The electrocatalysts were investigated by means of cyclic voltammetry and $\mathrm{CO}_{\mathrm{ads}}$ stripping voltammetry techniques in a standard three-electrode electrochemical cell. The applied electrolyte was $0.5 \mathrm{M} \mathrm{H}_{2} \mathrm{SO}_{4}$. The working electrode was prepared by dipping a drop of catalyst ink on a freshly polished glassy carbon electrode $(\mathrm{d}=0.3 \mathrm{~cm}$, geometric surface area $\mathrm{A}=0.0707$ $\mathrm{cm}^{2}$ ), and air-drying at room temperature for $30 \mathrm{~min}$. The Pt loading of the electrodes was 10 $\mu \mathrm{g} \mathrm{cm}^{-2}$. For the catalyst ink $5 \mathrm{mg}$ catalyst sample was suspended in $4 \mathrm{ml} \mathrm{H} 2 \mathrm{O}+1 \mathrm{ml}$ isopropanol $+20 \mu 1$ Nafion solution (D520 Nafion Dispersion - Alcohol based $1000 \mathrm{EW}$ at $5 \mathrm{wt} \%$, DuPont ${ }^{\mathrm{TM}}$ Nafion $\left.{ }^{\circledR}\right)$. The reference electrode was a hydrogen electrode immersed in the same electrolyte as the working electrode and all potentials are given on the RHE scale. Pt wire was used as the counter electrode. In the so-called "pre-leaching" procedure, the samples were submitted to cyclic polarization with $100 \mathrm{mV} \mathrm{s}^{-1}$ for 30 cycles between 50 and $1000 \mathrm{mV}$ potential limits.

In order to get information on the initial behavior of the electrocatalysts, $\mathrm{CO}_{\mathrm{ads}}$ stripping voltammetry measurements were carried out on the samples without any electrochemical preconditioning or cleaning, and after the "pre-leaching" treatment.

For $\mathrm{CO}_{\text {ads }}$ stripping voltammetry gaseous $\mathrm{CO}$ was fed into the cell for 20 min while maintaining a constant potential of $50 \mathrm{mV}$. Two types of $\mathrm{CO}_{\mathrm{ads}}$ stripping methods are distinguished according to the way how the physically adsorbed $\mathrm{CO}$ from the surface and dissolved $\mathrm{CO}$ from the electrolyte was removed. In case of so called Ar-purged and $\mathrm{H}_{2}$-purged $\mathrm{CO}_{\text {ads }}$ stripping methods $\mathrm{Ar}$ or $\mathrm{H}_{2}$ streams were bubbled through the electrolyte, respectively. After $\mathrm{Ar}$ or $\mathrm{H}_{2}$ purge for $20 \mathrm{~min}$, the working electrode was subjected to a cyclic voltammetry scans at a $10 \mathrm{mV} \mathrm{s}^{-1}$ scan rate between 50 and $1000 \mathrm{mV}$. During the first cycle, the chemically adsorbed $\mathrm{CO}$ was oxidized $\left({ }^{\mathrm{st}} \mathrm{CO}\right.$ stripping), then after the $\mathrm{CO}$ electrooxidation, another cyclic voltammogram was recorded. After the first CO stripping measurement the electrode was subjected to 30 cycles of the "pre-leaching" procedure at a $100 \mathrm{mV} \mathrm{s}^{-1}$ scan rate between 50 and $1000 \mathrm{mV}$. Then the above described CO stripping measurement was repeated ( $2^{\text {nd }} \mathrm{CO}$ stripping). After the $2^{\text {nd }} \mathrm{CO}_{\text {ads }}$ stripping measurement the cyclic voltammogram was recorded again. Relative errors were calculated as the standard deviation of at least three independent measurements.

For comparison as reference commercially available $20 \mathrm{wt} \%$ Pt (Quintech, C-20-Pt, on Vulcan; denoted hereafter as $20 \mathrm{Pt} / \mathrm{C}$ ) and $\mathrm{PtRu} / \mathrm{C}$, considered as the state-of-the art CO-tolerant electrocatalyst (Quintech, C-20-/10-Pt/Ru, Pt= $20 \mathrm{wt} \%, \mathrm{Ru}=10 \mathrm{wt} \%$ on Vulcan; denoted hereafter as $\mathrm{PtRu} / \mathrm{C}$ ) were also studied by the same method as described above.

\section{Results and discussion}

Characterization of the $\mathrm{Ti}_{(1-x)} \mathrm{Mo}_{x} \mathrm{O}_{2}-\mathrm{C}$ composite materials and the related Pt catalysts

The structure of the $\mathrm{Ti}_{(1-\mathrm{x})} \mathrm{Mo}_{\mathrm{x}} \mathrm{O}_{2}-\mathrm{C}$ composite materials was investigated by XRD measurements to evaluate the phase composition of the materials and determine the lattice parameters. Fig. 1 shows the XRD patterns of the composite samples before (Fig. 1A) and after the high-temperature treatment (HTT) (Fig. 1B). The results are also summarized in Table 2. 

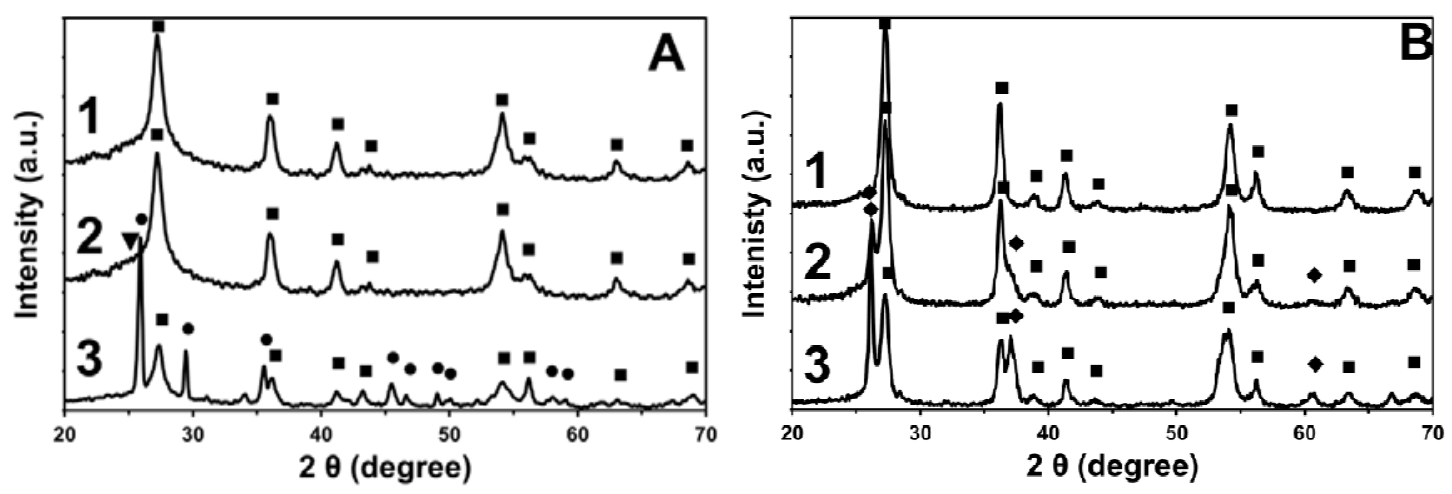

Fig. 1 XRD patterns of $\mathrm{Ti}_{(1-\mathrm{x})} \mathrm{Mo}_{\mathrm{x}} \mathrm{O}_{2}-\mathrm{C}$ samples before $(\mathrm{A})$ and after high-temperature treatment (B). 1: $\mathrm{Ti}_{0.8} \mathrm{Mo}_{0.2} \mathrm{O}_{2}-\mathrm{C} ; 2: \mathrm{Ti}_{0.7} \mathrm{Mo}_{0.3} \mathrm{O}_{2}-\mathrm{C} ; 3: \mathrm{Ti}_{0.6} \mathrm{Mo}_{0.4} \mathrm{O}_{2}-\mathrm{C}$. $\boldsymbol{\square}$ - rutile; $\boldsymbol{\nabla}$ - anatase; $\bullet-\mathrm{MoO}_{3}$; $\checkmark-\mathrm{MoO}_{2}$.

Upon preparation of the $\mathrm{Ti}_{0.7} \mathrm{~W}_{0.3} \mathrm{O}_{2}-\mathrm{C}$ composite materials we have found $[22,23]$ that preliminary formation of the rutile- $\mathrm{TiO}_{2}$ phase is a necessary condition for complete isovalent $\mathrm{W}$ incorporation into the rutile lattice upon the following reductive treatment. Accordingly, in the course of preparation of Mo-containing composite materials, our goals were: (i) to produce $\mathrm{Ti}_{(1-}$ $\left.{ }_{x}\right) \mathrm{Mo}_{\mathrm{x}} \mathrm{O}_{2}$ rutile phase with high crystallinity and (ii) to transform of Mo into oxidation state of four. Computer modelling of a $\mathrm{Ti}_{(1-\mathrm{x})} \mathrm{W}_{\mathrm{x}} \mathrm{O}_{2}$ mixed oxide revealed [30] that the unit cell parameters and volume of the rutile lattice change significantly, as a result of tungsten incorporation. Therefore, it is assumed that the rutile lattice distortion can be used as an indicator of the dopant incorporation.

The samples obtained before HTT consist of rutile crystallites (Fig. 1A). In the case of sample $\mathrm{Ti}_{0.6} \mathrm{Mo}_{0.4} \mathrm{O}_{2}-\mathrm{C}$ a small amount of $\mathrm{MoO}_{3}$ was also detected (see Table 2), due to the greater amount of molybdenum precursor used upon the preparation (rutile/ $\mathrm{MoO}_{3}=72 / 28$ ). At the other two samples with less nominal Mo content there were no reflections characteristic to $\mathrm{MoO}_{3}$ found, which may be attributed to the presence of amorphous $\mathrm{MoO}_{3}$ or crystalline $\mathrm{MoO}_{3}$ below the detection limit.

Table 2. Structural properties of the $\mathrm{Ti}_{(1-\mathrm{x})} \mathrm{Mo}_{\mathrm{x}} \mathrm{O}_{2}-\mathrm{C}$ composite materials determined by XRD analysis.

\begin{tabular}{|c|c|c|c|c|c|c|c|c|}
\hline \multirow[t]{2}{*}{ Samples $^{\text {a) }}$} & \multicolumn{3}{|c|}{ WHTT $^{\text {b) }}$ (Phase, \%) } & \multicolumn{3}{|c|}{ HTT $^{c)}$ (Phase, \%) } & \multirow{2}{*}{$\begin{array}{c}\text { Lattice parameters, } \\
\qquad \AA^{\text {d) }}\end{array}$} & \multirow{2}{*}{$\begin{array}{c}\text { Mo subst., } \\
\%\end{array}$} \\
\hline & $\mathbf{R}$ & $\mathbf{A}$ & $\mathrm{MoO}_{3} / \mathrm{MoO}_{2}$ & $\overline{\mathbf{R}}$ & A & $\mathrm{MoO}_{3} / \mathrm{MoO}_{2}$ & & \\
\hline $\mathrm{Ti}_{0.8} \mathrm{Mo}_{0.2} \mathrm{O}_{2}-\mathrm{C}$ & 100 & 0 & $0 / 0$ & 90 & 10 & $0 / 0$ & $a=4.640, c=2.935$ & 21 \\
\hline $\mathrm{Ti}_{0.7} \mathrm{Mo}_{0.3} \mathrm{O}_{2}-\mathrm{C}$ & 90 & 10 & $0 / 0$ & 86 & 10 & $0 / 4$ & $a=4.645, c=2.932$ & 25 \\
\hline $\mathrm{Ti}_{0.6} \mathrm{Mo}_{0.4} \mathrm{O}_{2}-\mathrm{C}$ & 72 & 0 & $28 / 0$ & 80 & 5 & $0 / 15$ & $a=4.655, c=2.928$ & 30 \\
\hline $\begin{array}{l}\text { a) Expected com } \\
\text { b) WHTT (witho } \\
\text { c) Detailed descr } \\
\text { d) Lattice parame } \\
\text { R: rutile, A: ana }\end{array}$ & of & $\begin{array}{l}\text { mp } \\
\text { he } \\
\text { e ru }\end{array}$ & $\begin{array}{l}-\mathrm{x}) \mathrm{Mo}_{\mathrm{x}} \mathrm{O}_{2} \text { mixec } \\
\text { ature treatment } \\
\text { TT applied was } \\
\text { le phase obtain }\end{array}$ & On & Fig & $\begin{array}{l}\text { esired } \mathrm{Ti} / \mathrm{Mo} \text { at } \\
\text { ere studied befo } \\
\text { (see Experimer } \\
\text { re rutile } \mathrm{TiO}_{2} \text { : }\end{array}$ & $\begin{array}{l}\text { nic ratio; } \\
\text { any HTT; } \\
1 \text { part); } \\
4.593 \AA, c=2.959 \AA ;\end{array}$ & \\
\hline
\end{tabular}


After the heat treatment (see Fig. 1B) almost pure rutile phase was obtained along with a small amount of both the anatase (5-10 \%) and $\mathrm{MoO}_{2}(4-15 \%)$ phases. The lattice parameters of the rutile phase after heat treatment are also given in Table 2. A comparison with the lattice parameters of pure rutile $\mathrm{TiO}_{2}$ indicates the expected distortion and confirm the presence of molybdenum incorporated into the unit cell; the degree of Mo incorporation increases to quite high values $\left(\mathrm{Mo}_{\text {subst }}=21-30 \%\right)$. The presence of the $\mathrm{MoO}_{2}$ phase indicates, however, that a certain fraction of Mo ions remains outside of the titania lattice and condensates into Mo-oxide particles located on the surface of the composite support. According to the XRD data, the amount of free, i.e. unincorporated $\mathrm{MoO}_{2}$ phase also increased with increasing nominal molybdenum content. It seems that incorporation of molybdenum under the used conditions has a maximum.

\section{Transmission electron microscopy (TEM) investigations}

TEM micrograph, electron diffraction pattern and particle size distribution of the $20 \mathrm{wt} . \%$ $\mathrm{Pt} / \mathrm{Ti}_{0.8} \mathrm{Mo}_{0.2} \mathrm{O}_{2}-\mathrm{C}$ catalyst are shown in Figure 2. Very similar morphologies were observed for the $\mathrm{Pt} / \mathrm{Ti}_{0.7} \mathrm{Mo}_{0.3} \mathrm{O}_{2}-\mathrm{C}$ and the $\mathrm{Pt} / \mathrm{Ti}_{0.6} \mathrm{Mo}_{0.4} \mathrm{O}_{2}-\mathrm{C}$ catalysts; micrographs, electron diffraction patterns and histograms for particle size distribution for these samples are presented in Figs. S3 and S4 of the Supplementary Material.
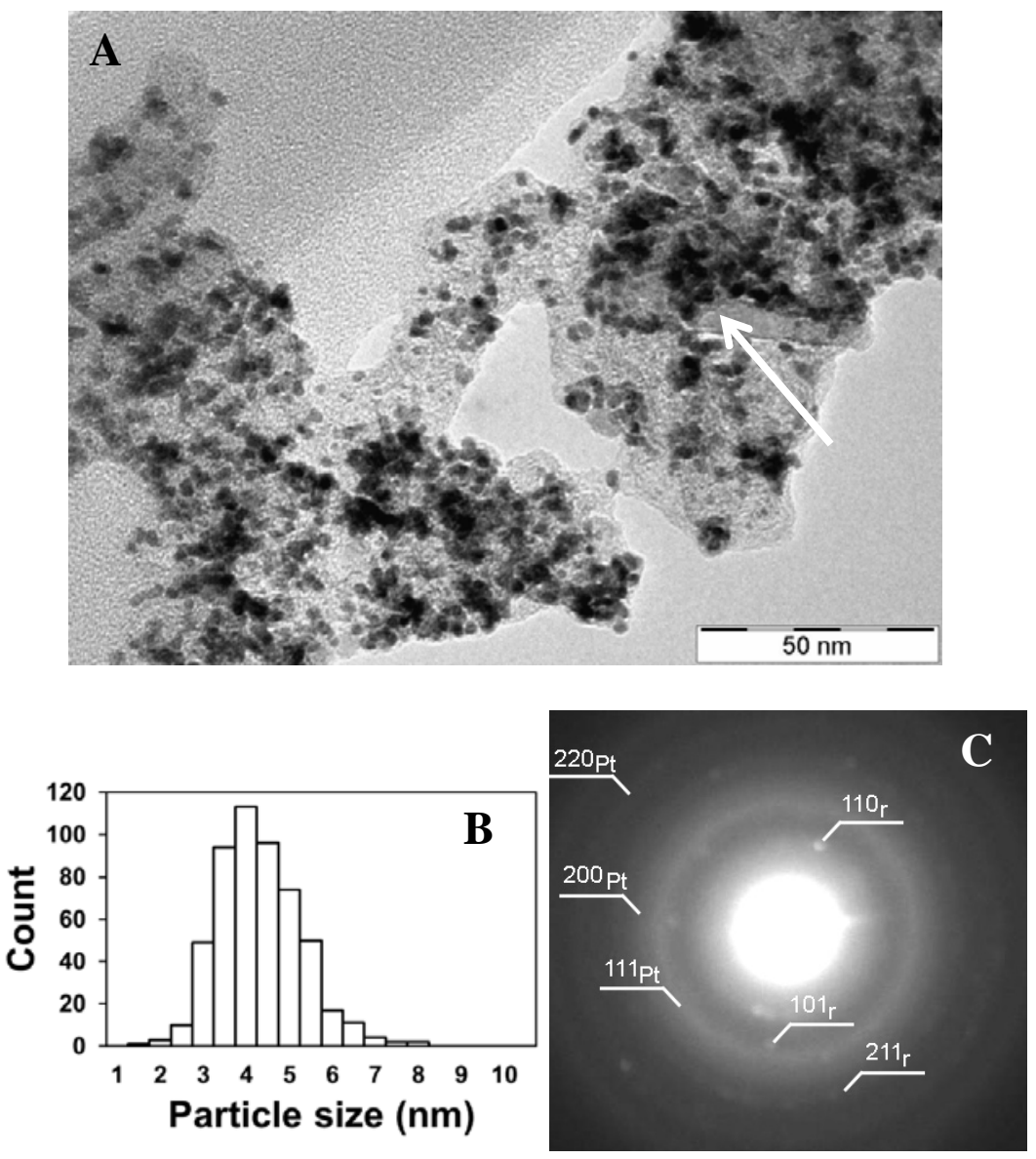

Fig. 2 TEM images (A), histogram of the Pt particle size distribution (B) and electron diffraction pattern (C) of the $\mathrm{Pt} / \mathrm{Ti}_{0.8} \mathrm{Mo}_{0.2} \mathrm{O}_{2}-\mathrm{C}$ electrocatalyst; " $r$ " stands for the Mo-doped rutile phase. 
Figs. 2 and Figs. S3 and S4 of the Supplementary Material reveal the uniform distribution of the Pt particles with mean particle size of $3.5 \pm 0.9 \mathrm{~nm}, 3.7 \pm 1 \mathrm{~nm}$ and $3.2 \pm 0.8 \mathrm{~nm}$ for samples with $\mathrm{x}=0.2,0.3$ and 0.4 nominal Mo content, respectively. It can be concluded that the applied reduction-precipitation method leads to fine dispersion of the Pt particles. Within the experimental error, the Mo content has practically no effect on the average particle size and on the particle size distribution, either.

In good accordance with XRD result, electron diffraction patterns revealed the presence of Mo-doped rutile phase in the samples. The micrographs reveal the coexistence of a few large, faceted nanorod-like mixed oxide rutile crystallites (indicated by white arrows) with the carboncontaining composite material; their presence is attributed to the relatively high mixed oxide content of the samples, as in micrographs of a composite with $50 \mathrm{wt} \%$ mixed oxide $-50 \mathrm{wt} \%$ active carbon no such crystallites were observed $[22,23]$.

Diffraction patterns corresponding to the platinum crystallites also appear, although there is considerable overlap between features arising from rutile and fcc $\mathrm{Pt}$ (see Fig. 2C and Figs. S3C and S4C of the Supplementary Material). Additionally, it can be seen that platinum nanoparticles are deposited onto the surface of both the large mixed oxide crystallites and the composite material.

\section{Energy-dispersive $X$-ray spectroscopy (EDX) measurement}

The elemental composition of the platinum loaded electrtocatalyst samples was evaluated by analyzing different regions by EDX technique; the average composition values are collected in Table 3.

Table 3. Composition of Pt loaded electrocatalyst samples measured by XRD, EDX and XPS in comparison with nominal values.

\begin{tabular}{|c|c|c|c|c|c|c|}
\hline Samples $^{\text {a) }}$ & $\begin{array}{c}\text { Mo }_{\text {subst•, }} \\
\% \\
\text { XRD } \\
\end{array}$ & $\begin{array}{c}\text { Ti/Mo (at/at) } \\
\text { EDX }\end{array}$ & $\begin{array}{c}\text { Ti/Mo } \\
\text { (at/at) } \\
\text { XPS } \\
\end{array}$ & $\begin{array}{c}\mathrm{Ti}+\mathrm{Mo}+\mathrm{O}) / \mathrm{C} \\
(\mathrm{wt} / \mathrm{wt}) \\
\text { EDX }\end{array}$ & $\begin{array}{c}\mathrm{Ti}+\mathrm{Mo}+\mathrm{O}) / \mathrm{C} \\
(\mathrm{wt} / \mathrm{wt}) \\
\text { XPS }\end{array}$ & $\begin{array}{c}\text { Pt } \\
(w t \%) \\
\text { EDX }\end{array}$ \\
\hline $\mathrm{Pt} / \mathrm{Ti}_{0.8} \mathrm{Mo}_{0.2} \mathrm{O}_{2}-\mathrm{C}$ & 20 & $83.7 / 16.3 \pm 1.7$ & $77.3 / 22.7$ & $68.9 / 31.1 \pm 1.8$ & $55.5 / 44.5$ & $20.1 \pm 0.6$ \\
\hline $\mathrm{Pt} / \mathrm{Ti}_{0.7} \mathrm{Mo}_{0.3} \mathrm{O}_{2}-\mathrm{C}$ & 25 & $78.4 / 21.6 \pm 3.8$ & $73.7 / 26.3$ & $66.1 / 33.9 \pm 1.3$ & $58.6 / 41.4$ & $21.9 \pm 0.4$ \\
\hline $\mathrm{Pt} / \mathrm{Ti}_{0.6} \mathrm{Mo}_{0.4} \mathrm{O}_{2}-\mathrm{C}$ & 28 & $74.7 / 25.3 \pm 0.8$ & $62.6 / 37.4$ & $64.5 / 35.5 \pm 2.3$ & $57.4 / 42.6$ & $19.2 \pm 0.8$ \\
\hline
\end{tabular}

a) Expected composition of $\mathrm{Ti}_{(1-\mathrm{x})} \mathrm{Mo}_{\mathrm{x}} \mathrm{O}_{2}$ mixed oxide reflects desired Ti/Mo atomic ratio

Standard deviations in compositional values proved to be small, indicating that the atomic composition of the samples and the individual particles was highly homogenous. As far the $\mathrm{Pt}$ content is related, the nominal and measured values are in good agreement, confirming the success of the uniform deposition of the $\mathrm{Pt}$ nanoparticles on the $\mathrm{Ti}_{(1-\mathrm{x})} \mathrm{Mo}_{\mathrm{x}} \mathrm{O}_{2}-\mathrm{C}$ composite materials, as already demonstrated on the TEM images.

However, there is some increase in the Ti/Mo ratios when measured values are compared to nominal ones. This phenomenon is quite unexpected as Mo addition to the samples was a simple impregnation which was followed by a HTT. These steps would not lead to Mo release from the catalysts. Such a Mo loss can only be explained by acidic experimental conditions upon Pt loading. The decrease of the relative molybdenum content is presumably the consequence of partial dissolution of the less stable Mo species, not incorporated into the lattice, upon $\mathrm{Pt}$ deposition. Probably this Mo loss explains why the $\mathrm{Ti}_{(1-\mathrm{x})} \mathrm{Mo}_{\mathrm{x}} \mathrm{O}_{2} / \mathrm{C}$ weight ratios measured by EDX are also smaller than expected. 
$X$-ray photoelectron spectroscopy (XPS) examination

In order to assess the surface composition of the investigated $\mathrm{Pt} / \mathrm{Ti}_{(1-\mathrm{x})} \mathrm{Mo}_{\mathrm{x}} \mathrm{O}_{2}-\mathrm{C}$ electrocatalysts, XPS measurements were carried out on samples in the as prepared state (i.e. after $8 \mathrm{~h}$ annealing in $\mathrm{Ar}$ at $600^{\circ} \mathrm{C}$ ). The observed composition data and the chemical states of the constituents are summarized in the following Table 4.

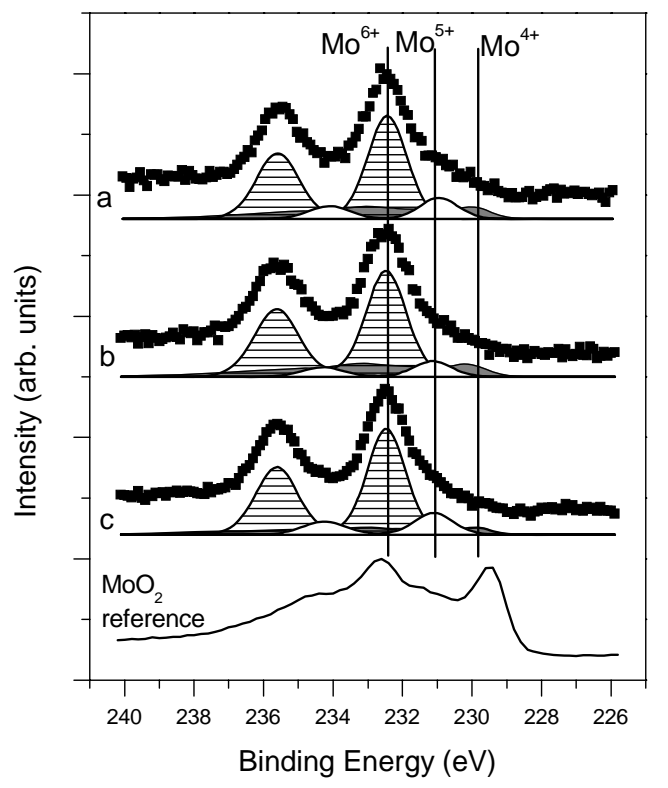

Fig. 3 Mo $3 \mathrm{~d}$ XPS spectra of the $\mathrm{Pt} / \mathrm{Ti}_{0.8} \mathrm{Mo}_{0.2} \mathrm{O}_{2}-\mathrm{C}$ (a), the $\mathrm{Pt} / \mathrm{Ti}_{0.7} \mathrm{Mo}_{0.3} \mathrm{O}_{2}-\mathrm{C}$ (b), and the $\mathrm{Pt} / \mathrm{Ti}_{0.6} \mathrm{Mo}_{0.4} \mathrm{O}_{2}-\mathrm{C}$ (c) electrocatalysts, along with the reference spectrum of $\mathrm{MoO}_{2}$. $\square$ : $\mathrm{Mo}^{4+}$, $\square: \mathrm{Mo}^{5+}$, 点: $\mathrm{Mo}^{6+}$.

The ratio of the Ti- and Mo-content corresponds acceptably to the nominal composition in all three cases. which is in contrast to the findings of EDX. Actually, as XPS is more surface sensitive than EDX, the relative abundance of Mo as deduced from the XPS measurement suggests accumulation of non-incorporated Mo on the surface, probably in the form of less stable species. On the other hand, the oxygen content is always somewhat more than the nominal value (even with the assumption of Mo being completely in the $6+$ oxidation state), suggesting the presence of excess surface oxygen species. Indeed, although the most intense contribution to the $\mathrm{O} 1 \mathrm{~s}$ line occurs at a binding energy characteristic for $\mathrm{TiO}_{2}$-related materials [31], the line shape is asymmetric towards higher binding energies, which can be related to the occurrence of surface hydroxyl groups and adsorbed water (spectra not shown). The carbon content of the samples is predominantly in the graphitic form; both EDX and XPS analysis indicate more carbon than the nominal value. In contrast to the EDX results, the concentration of Pt derived from XPS data is substantially more than the nominal $20 \mathrm{wt} . \%$, which may be due to the well dispersed nature of Pt. Pt is predominantly metallic with a $\mathrm{Pt} 4 \mathrm{f}_{7 / 2}$ binding energy slightly above $71 \mathrm{eV}$. A weak contribution around $72.5 \mathrm{eV}$ arises from $\mathrm{Pt}^{2+}$ species, which probably formed as a result of air exposure after synthesis. 

Table 4. Summary of the XPS analysis of the $20 \mathrm{Pt} / \mathrm{Ti}_{(1-\mathrm{x})} \mathrm{Mo}_{\mathrm{x}} \mathrm{O}_{2}-\mathrm{C}$ samples (the samples were used in the as prepared state).

\begin{tabular}{|c|c|c|c|c|c|c|c|c|c|c|c|c|c|c|c|}
\hline \multirow[t]{3}{*}{ Sample } & \multicolumn{15}{|c|}{ Element (photoelectron peak, binding energy (eV), chemical state, concentration (atomic \%)) } \\
\hline & \multicolumn{3}{|c|}{$\mathbf{P t} \mathbf{4 \mathbf { f } _ { 7 / 2 }}$} & \multicolumn{3}{|c|}{ Mo 3d $\mathbf{d}_{5 / 2}$} & \multicolumn{3}{|c|}{ Ti $2 \mathbf{p}_{3 / 2}$} & \multicolumn{3}{|l|}{ O 1s } & \multicolumn{3}{|l|}{ C 1s } \\
\hline & $\overline{\mathbf{B E}}$ & $\begin{array}{l}\text { Ch. } \\
\text { state }\end{array}$ & Conc. & $\overline{B E}$ & $\begin{array}{l}\text { Ch. } \\
\text { state }\end{array}$ & Conc. & $\overline{B E}$ & $\begin{array}{l}\text { Ch. } \\
\text { state }\end{array}$ & Conc. & $\mathbf{B E}$ & $\begin{array}{l}\begin{array}{l}\text { Ch. } \\
\text { state }\end{array} \\
\end{array}$ & Conc. & $\overline{B E}$ & $\begin{array}{l}\text { Ch. } \\
\text { state }\end{array}$ & Conc. \\
\hline $\mathrm{Pt} / \mathrm{Ti}_{0.8} \mathrm{Mo}_{0.2} \mathrm{O}_{2}-\mathrm{C}$ & $\begin{array}{l}71.1 \\
72.6\end{array}$ & $\begin{array}{l}\text { metal } \\
\mathrm{Pt}^{2+}\end{array}$ & 6.5 & $\begin{array}{l}229.9 \\
231.1 \\
232.4\end{array}$ & $\begin{array}{l}\mathrm{Mo}^{4+} \\
\mathrm{Mo}^{5+} \\
\mathrm{Mo}^{6+}\end{array}$ & 1.9 & 458.8 & $\mathrm{Ti}^{4+}$ & 6.5 & 530.2 & M-ox & 25.3 & 284.4 & $\begin{array}{l}\text { Gra- } \\
\text { phite }\end{array}$ & 59.8 \\
\hline $\mathrm{Pt} / \mathrm{Ti}_{0.7} \mathrm{Mo}_{0.3} \mathrm{O}_{2}-\mathrm{C}$ & $\begin{array}{l}71.2 \\
72.5\end{array}$ & $\begin{array}{l}\text { metal } \\
\mathrm{Pt}^{2+}\end{array}$ & 6.3 & $\begin{array}{l}230.0 \\
231.1 \\
232.5\end{array}$ & $\begin{array}{l}\mathrm{Mo}^{4+} \\
\mathrm{Mo}^{5+} \\
\mathrm{Mo}^{6+}\end{array}$ & 2.4 & 458.8 & $\mathrm{Ti}^{4+}$ & 6.7 & 530.3 & M-ox & 26.9 & 284.4 & $\begin{array}{l}\text { Gra- } \\
\text { phite }\end{array}$ & 57.7 \\
\hline $\mathrm{Pt} / \mathrm{Ti}_{0.6} \mathrm{Mo}_{0.4} \mathrm{O}_{2}-\mathrm{C}$ & $\begin{array}{l}71.1 \\
72.5\end{array}$ & $\begin{array}{l}\text { metal } \\
\mathrm{Pt}^{2+}\end{array}$ & 5.8 & $\begin{array}{l}229.9 \\
231.1 \\
232.5\end{array}$ & $\begin{array}{l}\mathrm{Mo}^{4+} \\
\mathrm{Mo}^{5+} \\
\mathrm{Mo}^{6+}\end{array}$ & 3.2 & 458.8 & $\mathrm{Ti}^{4+}$ & 5.5 & 530.2 & M-ox & 24.4 & 284.4 & $\begin{array}{l}\text { Gra- } \\
\text { phite }\end{array}$ & 61.1 \\
\hline
\end{tabular}

M-ox stands for metal oxide 

According to the Ti $2 p$ spectra, titanium is fully oxidized and is in the +4 oxidation state in all samples.

In Fig. 3 the Mo $3 \mathrm{~d}$ spectra of the three samples are compared. All spectra are dominated by a strong peak pair located around 232.5 and $235.6 \mathrm{eV}$ binding energy; these contributions arise from the Mo $3 \mathrm{~d}_{5 / 2-3 / 2}$ spin-orbit doublet of $\mathrm{Mo}^{6+}\left(\mathrm{MoO}_{3}\right)$ [32]. Apart from this, a pronounced asymmetry on the low binding energy side of the spectra indicate the presence of Mo ions in lower oxidation state as well.

According to the literature, the $\mathrm{Mo}^{5+}$ ionic state is expected to give a peak pair around 231 $\mathrm{eV}$ [32]. The $\mathrm{Mo}^{4+}$ ionic state, on the other hand, is characterized by a more complex $3 \mathrm{~d}$ spectrum consisting of a combination of a narrower and a broad spin-orbit splitted doublet with the most intense contribution between 229-230 eV [33,34]; the two peak pairs represent differently screened final states. In this work the $\mathrm{Mo}^{4+}$ contribution was modeled by a line shape measured on a vacuum annealed $\mathrm{MoO}_{2}$ powder sample (lowermost spectrum of Fig. 3), The Mo $3 \mathrm{~d}$ spectra of the three samples were satisfactorily fitted with the $\mathrm{Mo}^{6+}, \mathrm{Mo}^{5+}$ and $\mathrm{Mo}^{4+}$ contributions, indicating that no metallic Mo species are on the surface. Modeling of the spectra suggests that for the $\mathrm{Pt} / \mathrm{Ti}_{0.8} \mathrm{Mo}_{0.2} \mathrm{O}_{2}-\mathrm{C}$ and the $\mathrm{Pt} / \mathrm{Ti}_{0.7} \mathrm{Mo}_{0.3} \mathrm{O}_{2}-\mathrm{C}$ samples roughly $20 \%$ of the Mo content is in the $4+$ state, while for the $\mathrm{Pt} / \mathrm{Ti}_{0.6} \mathrm{Mo}_{0.4} \mathrm{O}_{2}-\mathrm{C}$ catalyst this value decreases to around $10 \%$.

From our previous work with $\mathrm{Ti}_{(1-\mathrm{x})} \mathrm{W}_{\mathrm{x}} \mathrm{O}_{2}$ mixed oxide based electrocatalysts we know that air exposure results in excessive oxidation of tungsten into the +6 oxidation state, regardless to the extent of the incorporation of the doping metal. Similarly, in the case of the $\mathrm{Ti}_{(1-\mathrm{x})} \mathrm{Mo}_{\mathrm{x}} \mathrm{O}_{2-}$ based system we believe that air exposure induced oxidation of molybdenum leads to the dominance of the $\mathrm{Mo}^{6+}$ ionic state. The $\mathrm{Mo}^{4+}$ signal should mainly arise from Mo ions deeply incorporated into the rutile lattice, where they are protected from oxidation. The somewhat higher relative amount of strongly oxidized Mo species in the case of the $\mathrm{Pt} / \mathrm{Ti}_{0.6} \mathrm{Mo}_{0.4} \mathrm{O}_{2}-\mathrm{C}$ sample is thus in agreement with the higher amount of non-incorporated Mo deduced from the XRD data.

\section{Electrochemical measurement}

At first cyclic voltammograms measured on the $\mathrm{Pt} / \mathrm{Ti}_{(1-\mathrm{x})} \mathrm{Mo}_{\mathrm{x}} \mathrm{O}_{2}-\mathrm{C}$ catalysts at the beginning (Fig. 4A) and the end (Fig. 4B) of the "pre-leaching" process are presented along with those obtained on the $20 \mathrm{wt} \% \mathrm{Pt} / \mathrm{C}$ reference.
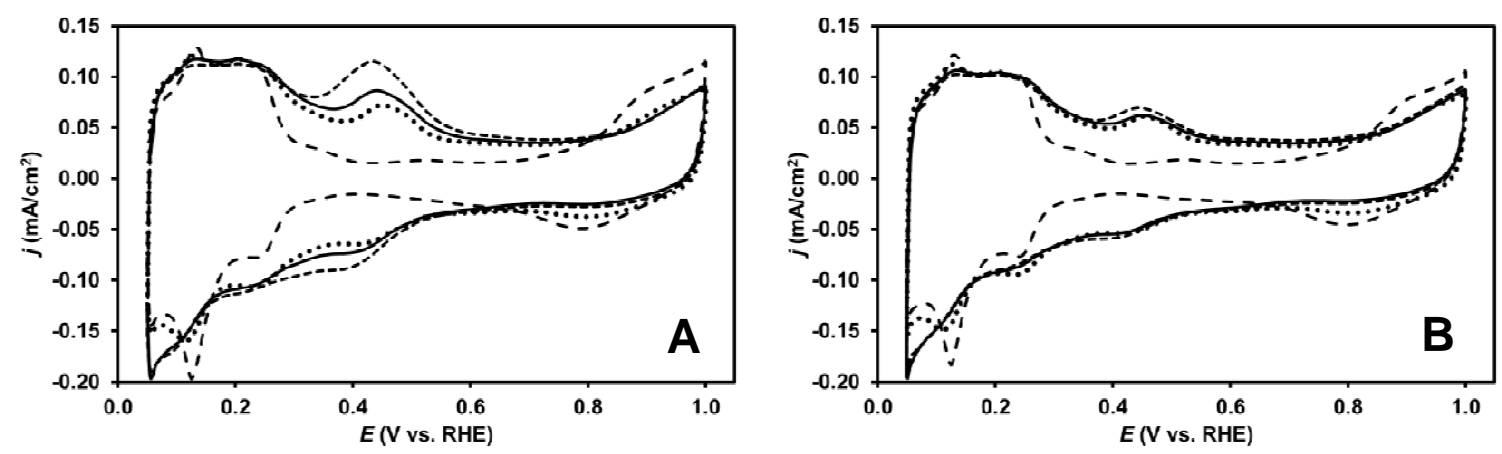

Fig. 4 Cyclic voltammograms of $\mathrm{Pt} / \mathrm{Ti}_{(1-x)} \mathrm{Mo}_{\mathrm{x}} \mathrm{O}_{2}-\mathrm{C}$ catalysts obtained after the $1^{\text {st }}(\mathrm{A})$ and the $2^{\text {nd }}$ $\mathrm{CO}_{\text {ads }}$ stripping measurements (B). Dotted line: $\mathrm{Pt} / \mathrm{Ti}_{0.8} \mathrm{Mo}_{0.2} \mathrm{O}_{2}-\mathrm{C}$; solid line: $\mathrm{Pt} / \mathrm{Ti}_{0.7} \mathrm{Mo}_{0.3} \mathrm{O}_{2}-\mathrm{C}$; short dashed line: $\mathrm{Pt} / \mathrm{Ti}_{0.6} \mathrm{Mo}_{0.4} \mathrm{O}_{2}-\mathrm{C}$. Results obtained on the parent $\mathrm{Pt} / \mathrm{C}$ catalyst (dashed line) are given for comparison. Recorded in $0.5 \mathrm{M} \mathrm{H}_{2} \mathrm{SO}_{4}$ at $10 \mathrm{mV} \mathrm{s}^{-1}, \mathrm{~T}=25^{\circ} \mathrm{C}$. The "pre-leaching" test for 30 cycles was carried out after the $1^{\text {st }}$ and before the $2^{\text {nd }} \mathrm{CO}_{\text {ads }}$ stripping measurement at $100 \mathrm{mV} \mathrm{s}^{-1}$. 

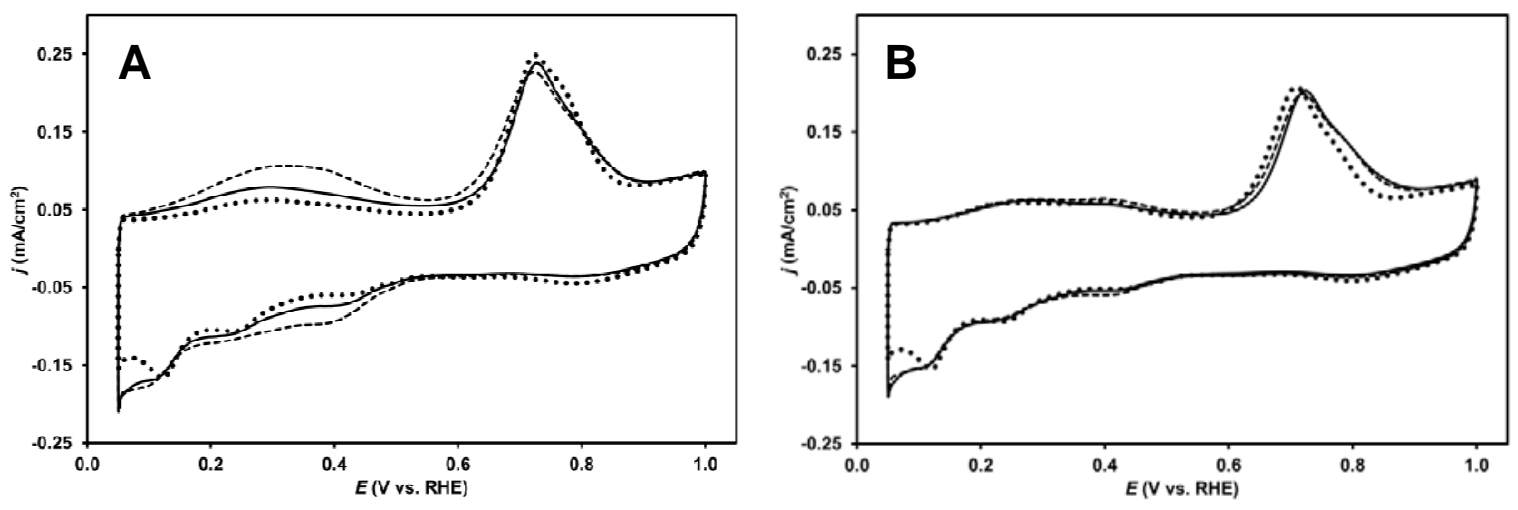

Fig. 5 Argon purged $\mathrm{CO}_{\text {ads }}$ stripping voltammograms of $\mathrm{Pt} / \mathrm{Ti}_{(1-\mathrm{x})} \mathrm{Mo}_{\mathrm{x}} \mathrm{O}_{2}-\mathrm{C}$ catalysts before (A) and after (B) the "pre-leaching" procedure. Dotted line: $\mathrm{Pt} / \mathrm{Ti}_{0.8} \mathrm{Mo}_{0.2} \mathrm{O}_{2} \mathrm{C}$; solid line: $\mathrm{Pt} / \mathrm{Ti}_{0.7} \mathrm{Mo}_{0.3} \mathrm{O}_{2}-\mathrm{C}$; dashed line: $\mathrm{Pt} / \mathrm{Ti}_{0.6} \mathrm{Mo}_{0.4} \mathrm{O}_{2}$-C. Recorded in $0.5 \mathrm{M} \mathrm{H}_{2} \mathrm{SO}_{4}$ at $10 \mathrm{mV} \mathrm{s}{ }^{-1}, \mathrm{~T}=25$ ${ }^{\circ} \mathrm{C}$. The "pre-leaching" was carried out for 30 cycles at $100 \mathrm{mV} \mathrm{s}^{-1}$.

A typical voltammogram of Pt electrocatalysts with the classical features of the underpotentially deposited hydrogen adsorption/desorption between $50 \mathrm{mV}$ and $350 \mathrm{mV}$ was observed on all samples (Fig. 4.). Besides, redox peaks between $380 \mathrm{mV}$ and $530 \mathrm{mV}$ were additionally detected on $\mathrm{Ti}_{(1-\mathrm{x})} \mathrm{Mo}_{\mathrm{x}} \mathrm{O}_{2}-\mathrm{C}$ composite supported Pt catalysts. Similar results have been reported for $\mathrm{Pt} / \mathrm{Ti}_{0.7} \mathrm{~W}_{0.3} \mathrm{O}_{2}$ electrocatalysts by Wang et al. [8]. An increased Coulombic charge of the hydrogen region was assigned to hydrogen spillover from $\mathrm{Pt}$ to the $\mathrm{Ti}_{0.7} \mathrm{~W}_{0.3} \mathrm{O}_{2}$ mixed oxide. As an analogy from the related art $[35,36]$ the redox peak pair observed in the $\mathrm{Pt} / \mathrm{Ti}_{(1-\mathrm{x})} \mathrm{Mo}_{\mathrm{x}} \mathrm{O}_{2}-\mathrm{C}$ samples can be interpreted as the intercalation/de-intercalation of $\mathrm{H}$ atoms into the $\mathrm{MoO}_{\mathrm{x}}$ lattice resulting in the formation/decomposition of hydrogen molybdenum bronze like species.

As shown in Fig. 4A the intensity of this redox peak pair depends on the Mo content in the samples and, as can be seen in Fig 4B, the decrease of the peak intensity was observed upon "pre-leaching". The data suggest that the free, unincorporated $\mathrm{MoO}_{\mathrm{x}}$ phase seems to have low resistance to synergic corrosion effect of acidic environment and cyclic polarization within a broad polarization window and may be dissolved upon aging.

According to the bifunctional mechanism the adsorbed hydroxyl species $\left(\mathrm{OH}_{\mathrm{ads}}\right)$ on oxophilic molybdenum is responsible for increased $\mathrm{CO}$ tolerance of the Mo-containing catalysts at very low electrode potentials [7,37]. Formation of surface hydroxyls are shown schematically by equation 1 :

$$
\mathrm{Pt}+\mathrm{MoO}_{x}+\mathrm{H}_{2} \mathrm{O} \rightarrow\left(\mathrm{MoO}_{x}\right)-\mathrm{OH}_{\mathrm{ads}}+\mathrm{Pt}-\mathrm{H}_{\mathrm{ads}}
$$

This is considered as the reactive moiety with adsorbed CO [38].

Furthermore, in acidic solutions molybdenum hydrogen bronze $\mathrm{H}_{\mathrm{y}} \mathrm{MoO}_{\mathrm{x}}$ could be formed by the "spillover" of hydrogen from Pt sites to Mo, that may have a contribution to enhanced catalytic activity toward $\mathrm{CO}$ electrooxidation $[7,18]$ :

$$
\begin{aligned}
& y \mathrm{Pt}-\mathrm{H}_{\mathrm{ads}}+\mathrm{MoO}_{x} \leftrightarrow \mathrm{H}_{y} \mathrm{MoO}_{x}+y \mathrm{Pt} \\
& \mathrm{H}_{y} \mathrm{MoO}_{x} \leftrightarrow \mathrm{MoO}_{x-y}-(\mathrm{OH})_{y}
\end{aligned}
$$


For such a process the close vicinity of the noble metal and $\mathrm{MoO}_{\mathrm{x}}$ species is prerequisite. Results of TEM measurement proved atomic closeness of the $\mathrm{Ti}_{(1-\mathrm{x})} \mathrm{Mo}_{\mathrm{x}} \mathrm{O}_{2}$ mixed-oxide and Pt.

In our case one may expect that during the $\mathrm{CV}$ measurements intercalation of hydrogen into non-incorporated, segregated $\mathrm{MoO}_{\mathrm{x}}$ oxide phase can result in a non-stoichiometric molybdenum hydrogen bronze $\mathrm{H}_{\mathrm{y}} \mathrm{MoO}_{\mathrm{x}}$ formation [7]. Hou et al. [17] proposed that hydrogen and $\mathrm{CO}$ spillover occur on $\mathrm{H}_{\mathrm{x}} \mathrm{MoO}_{3}$, which leads to the facile removal of $\mathrm{CO}$ by the active water bound on the $\mathrm{H}_{\mathrm{x}} \mathrm{MoO}_{3}$ in accordance with the bifunctional mechanism. Moreover the importance of hydrogen spillover from $\mathrm{Pt}$ to $\mathrm{Ti}_{0.7} \mathrm{~W}_{0.3} \mathrm{O}_{2}$ mixed oxides in the high activity for $\mathrm{CO}$ oxidation was demonstrated in Ref. [8]. Accordingly, in the $\mathrm{CO}_{\mathrm{ads}}$ stripping measurements very good initial $\mathrm{CO}$ tolerance is expected, which should change as the unincorporated $\mathrm{MoO}_{\mathrm{x}}$ species are dissolved during the "pre-leaching" treatment.

To investigate the influence of the mixed-oxide content of the support on the Pt catalyst in the presence of carbon-monoxide, Ar-purged $\mathrm{CO}_{\text {ads }}$ stripping voltammetry was performed using the different $\mathrm{Pt} / \mathrm{Ti}_{(1-\mathrm{x})} \mathrm{Mo}_{\mathrm{x}} \mathrm{O}_{2} \mathrm{C}$ samples (Fig. 5). The changes of the behavior of the $\mathrm{Pt} / \mathrm{Ti}_{0.8} \mathrm{Mo}_{0.2} \mathrm{O}_{2}-\mathrm{C}$ catalyst in Ar- and $\mathrm{H}_{2}$ purged $\mathrm{CO}_{\text {ads }}$ stripping as a result of the "pre-leaching" process are compared to those observed for $20 \mathrm{Pt} / \mathrm{C}$ and $\mathrm{PtRu} / \mathrm{C}$ reference catalysts (Quintech) as well (Fig. 6).

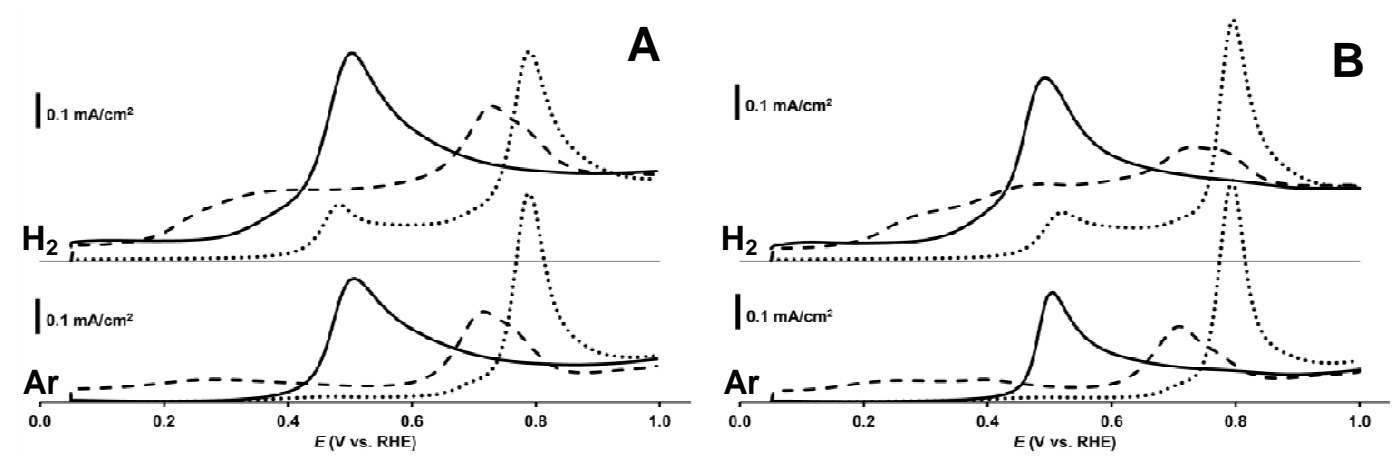

Fig. 6 The $1^{\text {st }}(\mathrm{A})$ and the $2^{\text {nd }} \mathrm{CO}_{\text {ads }}$ stripping voltammograms (B) obtained after Ar purging and $\mathrm{H}_{2}$ purging in the anodic scan on the $\mathrm{Pt} / \mathrm{Ti}_{0.8} \mathrm{Mo}_{0.2} \mathrm{O}_{2}-\mathrm{C}$ (dashed line), the $\mathrm{PtRu} / \mathrm{C}$ (solid line) and the Pt/C Quintech (dotted line) catalysts. Recorded in $0.5 \mathrm{~mol} \mathrm{dm}^{-3} \mathrm{H}_{2} \mathrm{SO}_{4}$ solution between 50 and $1000 \mathrm{mV}$ potential limits with $10 \mathrm{mV} \mathrm{s}^{-1}$ sweep rate. Before the $2^{\text {nd }} \mathrm{CO}_{\text {ads }}$ stripping measurements the "pre-leaching" procedure was performed in Ar purged $0.5 \mathrm{~mol} \mathrm{dm}^{-3} \mathrm{H}_{2} \mathrm{SO}_{4}$ solution between 50 and $1000 \mathrm{mV}$ potential limits with $100 \mathrm{mV} \mathrm{s}^{-1}$ sweep rate.

Ar-purged $\mathrm{CO}_{\mathrm{ads}}$ stripping results (Fig. 6) show that the onset potential corresponding to the $\mathrm{CO}$ oxidation reaction for $\mathrm{Pt} / \mathrm{Ti}_{(1-\mathrm{x})} \mathrm{Mo}_{\mathrm{x}} \mathrm{O}_{2}-\mathrm{C}$ catalysts shifts toward less positive potential values in comparison to that obtained over the reference $\mathrm{Pt} / \mathrm{C}$ sample. On the $20 \mathrm{Pt} / \mathrm{C}$ catalysts the main $\mathrm{CO}_{\text {ads }}$ stripping peak is located at ca. $795 \mathrm{mV}$ (see Table 5 and Fig. 6), while the corresponding peak in the case of the $\mathrm{Pt} / \mathrm{Ti}_{(1-\mathrm{x})} \mathrm{Mo}_{\mathrm{x}} \mathrm{O}_{2}-\mathrm{C}$ catalysts is around 705-725 $\mathrm{mV}$. Beyond the main peak two overlapping "pre-peaks" centered between ca. $200 \mathrm{mV}$ and $400 \mathrm{mV}$ can be seen over the Mo doped samples. These "pre-peaks" are typical for Pt-based catalysts containing $\mathrm{Ti}, \mathrm{Ta}, \mathrm{W}$, and Mo suboxides, and are generally attributed to oxidation of weakly bonded CO $[39,40]$. The results indicate that the composite supported Pt catalysts, by means of the Mo species in close contact to Pt nanoparticles, could supply a source of hydroxyl intermediates 
which are consumed during oxidation of $\mathrm{CO}$ to $\mathrm{CO}_{2}$, cleaning this way the $\mathrm{Pt}$ active site from $\mathrm{CO}$ poisoning species [7]:

$$
\left(\mathrm{MoO}_{x}\right)-\mathrm{OH}_{\mathrm{ads}}+\mathrm{Pt}-(\mathrm{CO})_{\mathrm{ads}} \rightarrow \mathrm{CO}_{2}+\mathrm{Pt}+\mathrm{MoO}_{x}+\mathrm{H}^{+}+\mathrm{e}^{-}
$$

Table 5. Influence of the $\mathrm{Ti} / \mathrm{Mo}$ ratio in $\mathrm{Ti}_{(1-\mathrm{x})} \mathrm{Mo}_{\mathrm{x}} \mathrm{O}_{2}$ mixed oxides on the electrochemical performance of the corresponding $\mathrm{Pt} / \mathrm{Ti}_{(1-\mathrm{x})} \mathrm{Mo}_{\mathrm{x}} \mathrm{O}_{2}-\mathrm{C}$ electrocatalysts. Results obtained on the parent $\mathrm{Pt} / \mathrm{C}$ and the $\mathrm{PtRu} / \mathrm{C}$ catalysts are given for comparison.

\begin{tabular}{|c|c|c|c|c|c|}
\hline Samples & $\begin{array}{c}\mathbf{E}_{\text {CO,onset, }}{ }^{\text {a) }} \\
\text { mV }\end{array}$ & $\begin{array}{c}\mathrm{E}_{\mathrm{CO}, \max }{ }^{\mathrm{b})} \\
\mathrm{mV}\end{array}$ & $\begin{array}{c}1^{\text {st }} \text { ECSA }_{\mathrm{CO}}{ }^{\mathrm{c}}{ }^{2} \\
\mathrm{~m}^{2} / \mathrm{g}_{\mathrm{Pt}}\end{array}$ & $\begin{array}{c}2^{\text {nd }} \operatorname{ECSA}_{\mathrm{CO}}{ }^{\text {c,d) }} \\
\mathrm{m}^{2} / \mathrm{g}_{\mathrm{Pt}}\end{array}$ & $\begin{array}{c}\text { Difference, }^{\mathrm{e})} \\
\% \\
\end{array}$ \\
\hline $\mathrm{Pt} / \mathrm{Ti}_{0.8} \mathrm{Mo}_{0.2} \mathrm{O}_{2}-\mathrm{C}$ & $50^{f)}$ & 705 & 72.9 & 58.1 & 20.3 \\
\hline $\mathrm{Pt} / \mathrm{Ti}_{0.7} \mathrm{Mo}_{0.3} \mathrm{O}_{2}-\mathrm{C}$ & $50^{f)}$ & 725 & 70.5 & 54.7 & 22.4 \\
\hline $\mathrm{Pt} / \mathrm{Ti}_{0.6} \mathrm{Mo}_{0.4} \mathrm{O}_{2}-\mathrm{C}$ & $50^{f)}$ & 715 & 73.4 & 55.8 & 24.0 \\
\hline $\mathrm{PtRu} / \mathrm{C}$ & 255 & 505 & 118.5 & 88.9 & 25.0 \\
\hline $\mathrm{Pt} / \mathrm{C}$ & 625 & 795 & 113.2 & 101.1 & 10.7 \\
\hline
\end{tabular}

a) The onset potential for the $\mathrm{CO}$ electrooxidation;

b) The position of the main $\mathrm{CO}_{\mathrm{ad}}$ stripping peak determined from the $2^{\text {nd }} \mathrm{CO}$-stripping measurements;

c) $1^{\text {st }}$ ECSA $_{\mathrm{CO}}$ and $2^{\text {nd }}$ ECSA $_{\mathrm{CO}}$ values were calculated from the $1^{\text {st }}$ and $2^{\text {nd }} \mathrm{CO}$-stripping measurements, respectively; upon calculation the area of the "pre-peak" was not taken into account.

d) Before the $2^{\text {nd }} \mathrm{CO}$-stripping measurements the "pre-leaching" test for 30 cycles at $100 \mathrm{mV} \mathrm{s}$ s $^{-1}$ was performed;

e) $\left\{1-\left(2^{\text {nd }} \mathrm{ECSA}_{\mathrm{CO}} / 1^{\text {st }} \mathrm{ECSA}_{\mathrm{CO}}\right)\right\} \times 100 \%$;

f) The $\mathrm{E}_{\mathrm{CO} \text {,onset }}$ of the "pre-peak" observed on $\mathrm{Pt} / \mathrm{Ti}_{(1-\mathrm{x})} \mathrm{Mo}_{\mathrm{x}} \mathrm{O}_{2}-\mathrm{C}$ catalysts.

On $\mathrm{CO}_{\text {ads }}$ stripping voltammograms after the "pre-leaching" process we observed the large decrease of the "pre-peak" mostly for samples $\mathrm{Pt} / \mathrm{Ti}_{0.7} \mathrm{Mo}_{0.3} \mathrm{O}_{2}-\mathrm{C}$ and $\mathrm{Pt} / \mathrm{Ti}_{0.6} \mathrm{Mo}_{0.4} \mathrm{O}_{2}-\mathrm{C}$ (Figure 5B). It appears that the current density values in this potential range became reduced to the level of the sample $\mathrm{Pt} / \mathrm{Ti}_{0.8} \mathrm{Mo}_{0.2} \mathrm{O}_{2}$-C. These observations support continuous removal/dissolution of Mo species from the surface and in the same time stabilization of the surface Ti/Mo ratio. One can suppose that free Mo species, i.e. those not incorporated into the rutile lattice, may be more sensitive to redox polarization than incorporated ones and thus may be removed when submitted to the "pre-leaching" procedure. These observations are in a good agreement with results presented in Ref. [41] obtained on the $\mathrm{Pt}_{0.8} \mathrm{Mo}_{0.2}$ alloy and $\mathrm{MoO}_{\mathrm{x}} @ \mathrm{Pt}$ core-shell anode electrocatalysts. It has been demonstrated [41] that even if the CO tolerance of the $\mathrm{MoO}_{\mathrm{x}} @ \mathrm{Pt}$ system with $\mathrm{MoO}_{\mathrm{x}}$ core and relatively low precious metal content is superior to $\mathrm{Pt}_{0.8} \mathrm{Mo}_{0.2}$ alloy catalyst, this catalyst has shown poor durability due to leaching of the Mo. The conclusion that unstable unincorporated Mo species are responsible for the good initial CO tolerance is further supported by Ref. [42], where the "pre-peak" of the $\mathrm{Pt} / \mathrm{Ti}_{3} \mathrm{O}_{5}$-Mo catalyst centered at ca. $450 \mathrm{mV}$ was attributed to the faradaic process of intercalation/de-intercalation of $\mathrm{H}$ atoms into the $\mathrm{MoO}_{\mathrm{y}}$ lattice. The disappearance of the Mo redox peak after 1000 cycles of cyclic polarization observed on this catalyst and decrease of the "pre-peak" intensity accompanied with simultaneous shift to higher potential in the CO stripping voltammograms were also demonstrated [42].

Accordingly, it can be stated that there are surface Mo species which survive the "preleaching" process and are quite stable. Considering the dependence of the extent of the changes of the $\mathrm{CO}_{\text {ads }}$ stripping behavior on the initial Mo content, these species can be identified as those incorporated into the rutile lattice. Apparently, when doped into $\mathrm{TiO}_{2}$ at low enough level, the oxophilic doping metal (W, and Mo) is protected from dissolution [43]. At the moment, the nature of the oxygenated species provided upon $\mathrm{H}^{+}$insertion (eq. (2)) and/or by chemisorption of 
water molecules (eq (1)) over the Mo-doped rutile matrix is still unclear. Nevertheless, our data show that these protected Mo species may have crucial importance on $\mathrm{CO}$ electrooxidation and therefore on long term $\mathrm{CO}$ tolerance of $\mathrm{Pt}$ based electrocatalysts.

We tested the $\mathrm{Pt} / \mathrm{Ti}_{0.8} \mathrm{Mo}_{0.2} \mathrm{O}_{2}$-C catalyst with high degree of Mo incorporation by argonand hydrogen-purged $\mathrm{CO}_{\text {ads }}$ stripping voltammetry before and after the "pre-leaching" process in comparison with reference commercial $\mathrm{Pt} / \mathrm{C}$ and $\mathrm{PtRu} / \mathrm{C}$ catalysts (see Fig. 6). Comparison of the $\mathrm{CO}_{\text {ads }}$ stripping behavior of the $\mathrm{Ti}_{0.8} \mathrm{Mo}_{0.2} \mathrm{O}_{2}$-C electrocatalyst to the $20 \mathrm{Pt} / \mathrm{C}$ catalyst (see Fig. 6) demonstrates increased $\mathrm{CO}$ tolerance of the composite supported catalyst. $\mathrm{CO}_{\mathrm{ads}}$ stripping voltammograms measured on the $\mathrm{Pt} / \mathrm{Ti}_{0.8} \mathrm{Mo}_{0.2} \mathrm{O}_{2}-\mathrm{C}$ sample before and after the "pre-leaching" process (Fig. 6A and B) confirm the good stability of the catalyst in this potential range. .According to the Ar-purged voltammograms, the onset potential for $\mathrm{CO}$ oxidation on the composite supported catalyst is not higher than $50 \mathrm{mV}$.

$\mathrm{H}_{2}$-purged $\mathrm{CO}_{a d s}$ stripping voltammetry reveals the potential at which vacancies are formed in the $\mathrm{CO}_{\text {ads }}$ monolayer $[44,45]$. Once $\mathrm{CO}$ desorbs from a fraction of the catalytic sites, Pt sites become available for the dissociation/electrooxidation of $\mathrm{H}_{2}$ molecules resulting in a steep increase of the current up to the diffusion-limited plateau [44-46].

The upper traces of Fig. 6A and 6B show the anodic current curves measured by $\mathrm{H}_{2}-$ purged $\mathrm{CO}_{\mathrm{ads}}$ stripping voltammetry before and after the "pre-leaching" process. On the $\mathrm{Pt} / \mathrm{Ti}_{0.8} \mathrm{Mo}_{0.2} \mathrm{O}_{2}-\mathrm{C}$ catalyst, an increase of the current at around $200 \mathrm{mV}$ is found, which means that the onset potential of hydrogen oxidation is shifted toward less positive potentials in comparison with $\mathrm{Pt} / \mathrm{C}$ and $\mathrm{PtRu} / \mathrm{C}$ (around 400 and $300 \mathrm{mV}$, respectively).

Ar- and $\mathrm{H}_{2}$-purged $\mathrm{CO}_{\text {ads }}$ stripping experiments were also performed with electrocatalysts with higher nominal Mo content. The results are summarized in Table 5. The data indicate the very good $\mathrm{CO}$ tolerance of the $\mathrm{Ti}_{(1-\mathrm{x})} \mathrm{Mo}_{\mathrm{x}} \mathrm{O}_{2}-\mathrm{C}$ composite supported electrocatalysts. The substantial decrease of the electrochemically active surface area during the "pre-leaching" treatment indicates the transition from a mechanism for $\mathrm{CO}$ tolerance dominated by interaction between $\mathrm{Pt}$ and unincorporated Mo-oxide to one in which Mo ions stabilized by incorporation into the rutile lattice are relevant. The notable decrease of the $\mathrm{ECSA}_{\mathrm{CO}}$ for $\mathrm{PtRu} / \mathrm{C}$ during the "pre-leaching" may point to the sensitivity for dissolution even in this system.

Based on all the presented results, we can conclude that our catalysts supported on the $\mathrm{Ti}_{(1-\mathrm{x})} \mathrm{Mo}_{\mathrm{x}} \mathrm{O}_{2}-\mathrm{C}$ composite material perform better than commercial $\mathrm{Pt} / \mathrm{C}$ or even $\mathrm{PtRu} / \mathrm{C}$. Our observations suggest that the optimal composition for the $\mathrm{Pt} / \mathrm{Ti}_{(1-\mathrm{x})} \mathrm{Mo}_{\mathrm{x}} \mathrm{O}_{2}-\mathrm{C}$ electrocatalysts prepared by our method is around $\mathrm{x}=0.2-0.25$.

\section{Conclusion}

As a continuation of our previous work, our aim was to investigate mixed titaniummolybdenum-oxide-carbon composite supported $\mathrm{Pt}$ electrocatalysts. $\mathrm{Ti}_{(1-\mathrm{x})} \mathrm{Mo}_{\mathrm{x}} \mathrm{O}_{2}-\mathrm{C}$ composite materials with three different $\mathrm{Ti}$ to Mo ratio were synthetized by a multistep sol-gel-based synthesis method followed by high-temperature heat treatment. According to the results of XRD measurements at the end of synthesis rutile phase was obtained with high degree of Mo incorporation. Nevertheless, incorporation in the case of samples containing more added molybdenum was found to be incomplete. It seems that incorporation of molybdenum under the used conditions has a maximum.

The $20 \mathrm{wt} . \%$ Pt loading was deposited onto the composite carrier via modified $\mathrm{NaBH}_{4}-$ assisted EG reduction-precipitation method. The results of EDX studies showed good agreement with the nominal composition of the $20 \mathrm{wt} . \%$ Pt loaded catalysts. A comparison of EDX and XPS data suggested surface enrichment of Mo and some Mo dissolution during Pt loading. 
Enhanced initial CO tolerance of the Pt electrocatalysts prepared by using the composite support materials were evidenced by the appearance of a CO-oxidation related "pre-peak" and by considerable shift of the maximum of the main $\mathrm{CO}$ oxidation peak towards less positive potential compared to the reference commercial $\mathrm{Pt} / \mathrm{C}$. The onset potential of $\mathrm{H}_{2}$ oxidation also shifted to lower potential in comparison with the reference catalyst. According to the results of electrochemical measurements there is a good correlation between the Mo content of the samples and the extent of $\mathrm{CO}$ tolerance.

However, the difference in the electrochemical behavior of the samples with different Ti/Mo ratio gradually disappeared as a result of the "pre-leaching" process. The amount of unincorporated Mo being present in the sample at the beginning dissolved during the "preleaching" treatment, so the extent and nature of the Pt-Mo interaction changed. From these results it can be concluded that although the high initial Mo concentration results in significant Pt-Mo interaction the unincorporated Mo is not stable and in long term use only the incorporated content is available and relevant.

\section{Acknowledgements}

This work was supported by the National Development Agency [grant number KTIA_AIK_12-12012-0014]. Financial support by the OTKA-project [grant numbers K100793 (Zoltán Pászti) and K112034 (István Bakos)] is greatly acknowledged.

\section{References}

[1] Meier JC, Galeano C, Katsounaros I, Topalov AA, Kostka A, Schuüth F, Mayrhofer KJJ (2012) Degradation Mechanisms of Pt/C Fuel Cell Catalysts under Simulated Start-Stop Conditions. ACS Catal 2:832-843

[2] Mathias MF, Makharia R, Gasteiger HA, Conley JJ, Fuller TJ, Gittleman CI, Kocha SS, Miller DP, Mittelsteadt CK, Xie T, Yan SG, Yu PT (2005) Two Fuel Cell cars in every garage? Electrochem. Soc. Interface 14:24-35

[3] Subban C, Zhou Q, Leonard B, Ranjan C, Edvenson HM, DiSalvo FJ, Munie S, Hunting J (2010) Catalyst supports for polymer electrolyte fuel cells. Phil. Trans. R. Soc. A 368:3243-3253

[4] Huang SY, Ganesan P, Popov BN (2012) Electrocatalytic activity and stability of titaniaSupported Platinum-Palladium electrocatalysts for Polymer Electrolyte Membrane Fuel Cell. ACS Catal 2:825-831

[5] Huang SY, Ganesan P, Popov BN (2009) Development of a Titanium Dioxide-Supported Platinum Catalyst with Ultrahigh Stability for Polymer Electrolyte Membrane Fuel Cell Applications. J Am Chem Soc 131:13898-13899

[6] Huang SY, Ganesan P, Popov BN (2011) Titania supported platinum catalyst with high electrocatalytic activity and stability for polymer electrolyte membrane fuel cell. Appl. Catal. BEnviron 102-71-77

[7] Zhang Z, Liu J, Gu J, Su L, Cheng L (2014) An overview of metal oxide materials as electrocatalysts and supports for polymer electrolyte fuel cells. Energy Environ Sc. 7:2535-2558

[8] Wang D, Subban CV, Wang H, Rus E, DiSalvo FJ, Abruña HD (2010) Highly Stable and CO-Tolerant $\mathrm{Pt} / \mathrm{Ti}_{0.7} \mathrm{~W}_{0.3} \mathrm{O}_{2}$ Electrocatalyst for Proton-Exchange Membrane Fuel Cells. J Am Chem Soc 132:10218-10220

[9] Chevallier L, Bauer A, Cavaliere S, Hui R, Rozière J, Jones DJ (2012) Mesoporous Nanostructured Nb-Doped Titanium Dioxide Microsphere Catalyst Supports for PEM Fuel Cell Electrodes. ACS Appl Mater Interfaces 4:1752-1759 
[10] Do TB, Cai M, Ruthkosky MS, Moylan TE (2010) Niobium-doped titanium oxide for fuel cell application. Electrochim Acta 55:8013-8017

[11] Kumar A, Ramani V. (2013) $\mathrm{Ta}_{0.3} \mathrm{Ti}_{0.7} \mathrm{O}_{2}$ Electrocatalyst Supports Exhibit Exceptional Electrochemical Stability. J Electrochem Soc 160:F1207-F1215

[12] Zeng J, Lee JY (2007) Ruthenium-free, carbon-supported cobalt and tungsten containing binary \& ternary Pt catalysts for the anodes of direct methanol fuel cells. Int J Hydrogen Energy 32:4389-4396

[13] Maillard F, Peyrelade E, Soldo-Olivier Y, Chatenet M, Chaînet E, Faure R (2007) Is carbonsupported Pt-WOx composite a CO-tolerant material? Electrochim Acta 52:1958-1967

[14] Pereira LGS, Paganin VA, Ticianelli EA (2009) Investigation of the CO tolerance mechanism at several Pt-based bimetallic anode electrocatalysts in a PEM fuel cell. Electrochim Acta 54:1992-1998

[15] Yavuz E, Özdokur KV, Cakar I, Kocak S, Ertas FN (2015) Electrochemical Preparation, Characterization of Molybdenum-Oxide/Platinum Binary Catalysts and Its Application to Oxygen Reduction Reaction in Weakly Acidic Medium. Electrochim Acta 151:72-80

[16] Igarashi H, Fujino T, Zhu Y, Uchida H, Watanabe M (2001) CO Tolerance of Pt alloy electrocatalysts for polymer electrolyte fuel cells and the detoxification mechanism. Phys Chem Chem Phys 3:306-314

[17] Hou Z, Yi B, Yu H, Lin Z, Zhang H (2003) CO tolerance electrocatalyst of PtRu- $\mathrm{H}_{\mathrm{x}} \mathrm{MeO}_{3} / \mathrm{C}$ $(\mathrm{Me}=\mathrm{W}, \mathrm{Mo})$ made by composite support method. J Power Sources 123:116-125

[18] Wang Y, Fachini ER, Cruz G, Zhu Y, Ishikawa Y, Colucci JA, Cabrera CR (2001) Effect of surface composition of electrochemically codeposited platinum/molybdenum oxide on methanol oxidation. J Electrochem Soc 148:C222-C226

[19] Santiago EI, Camara GA, Ticianelli EA (2003) CO tolerance on PtMo/C electrocatalysts prepared by the formic acid method. Electrochim Acta 48:3527-3534

[20] Ho VTT, Pan CJ, Rick J, Su WN, Hwang BJ (2011) Nanostructured $\mathrm{Ti}_{0.7} \mathrm{Mo}_{0.3} \mathrm{O}_{2}$ Support Enhances Electron Transfer to Pt: High-Performance Catalyst for Oxygen Reduction Reaction. J Am Chem Soc 133:11716-11724

[21] Nguyen TT, Ho VTT, Pan CJ, Liu JY, Chou HL, Rick J, Su WN, Hwang BJ (2014) Synthesis of $\mathrm{Ti}_{0.7} \mathrm{Mo}_{0.3} \mathrm{O}_{2}$ supported- Pt nanodendrites and their catalytic activity and stability for oxygen reduction reaction. Appl. Catal. B-Environ 154-155:183-189

[22] Gubán D, Borbáth I, Pászti Z, Sajó IE, Drotár E, Hegedűs M, Tompos A. (2015) Preparation and characterization of novel $\mathrm{Ti}_{0.7} \mathrm{~W}_{0.3} \mathrm{O}_{2}$-C composite materials for Pt-based anode electrocatalysts with enhanced CO tolerance. Appl Catal B-Environ 174:455-470

[23] Gubán D, Pászti Z, Borbáth I, Bakos I, Drotár E, Sajó IE, Tompos A. (2016) Design and preparation of $\mathrm{CO}$ tolerant anode electrocatalysts for PEM fuel cells. Period Polytech-Chem 60:29-39

[24] Kim P, Joo JB, Kim W, Kim J, Song IK, Yi, J. (2006) $\mathrm{NaBH}_{4}$-assisted ethylene glycol reduction for preparation of carbon-supported Pt catalyst for methanol electro-oxidation. J Power Sources 160: 987-990

[25] Fairley N (2006) "CasaXPS: Spectrum Processing Software for XPS, AES and SIMS," Version 2.3.13, Casa Software Ltd, Cheshire. http://www.casaxps.com

[26] Mohai M. "XPS MultiQuant: Multimodel XPS Quantification Software," Surface and Interface Analysis 36(8), pp. 828-832. 2004.

[27] Mohai M. (2011) "XPS MultiQuant: Multi-model X-ray photoelectron spectroscopy quantification program," Version 7.00.92. 
[28] Wagner CD, Naumkin AV, Kraut-Vass A, Allison JW, Powell CJ, Rumble JR. Jr (2003) „NIST X-ray Photoelectron Spectroscopy Database,” Version 3.4, National Institute of Standards and Technology, Gaithersburg, MD

[29] Moulder JF, Stickle WF, Sobol PE, Bomben K.D. (1992) "Handbook of X-ray Photoelectron Spectroscopy," Perkin-Elmer Corp., Eden Prairie, Minnesota, USA

[30] Peters E, Mueller-Buschbaum H. (1996) Ueber ein niedervalentes Titan-Wolframoxid: $\mathrm{Ti}_{0.54} \mathrm{~W}_{0.46} \mathrm{O}_{2}$. Zeitschrift fuer Naturforschung, Teil B. Anorganische Chemie, Organische Chemie 51:29-31. Crystallography Open Database: www.crystallography.net/2002761.html

[31] Atuchin VV, Kesler VG, Pervukhina NV, Zhang Z (2006) Ti 2p and O 1s core levels and chemical bonding in titanium-bearing oxides. J Electron Spectr Relat Phenom 152:18-24

[32] Baltrusaitis J, Mendoza-Sanchez B, Fernandez V, Veenstra R, Dukstiene N, Roberts A, Fairley N (2015) Generalized molybdenum oxide surface chemical state XPS determination via informed amorphous sample model. Appl Surf Sci 326:151-161

[33] Schroeder T, Zegenhagen J, Magg N, Immaraporn B, Freund HJ (2004) Formation of a faceted $\mathrm{MoO}_{2}$ epilayer on Mo(112) studied by XPS, UPS and STM. Surf Sci 552:85-97

[34] Scanlon DO, Watson GW, Payne DJ, Atkinson GR, Egdell RG, Law DSL (2010) Theoretical and Experimental Study of the Electronic Structures of $\mathrm{MoO}_{3}$ and $\mathrm{MoO}_{2}$. J Phys Chem C 114:4636-4645

[35] Mukerjee S, Urian RC (2002) Bifunctionality in Pt alloy nanocluster electrocatalysts for enhanced methanol oxidation and CO tolerance in PEM fuel cells: electrochemical and in situ synchrotron spectroscopy. Electrochim Acta 47: 3219-3231

[36] Justin P, Rao GR (2011) Methanol oxidation on $\mathrm{MoO}_{3}$ promoted Pt/C electrocatalyst. Int J Hydrogen Energy 36:5875-5884

[37] M.A. Scibioh MA, B. Viswanathan B (2012) In: Guczi L, Erdőhelyi A (eds) Catalysis for Alternative Energy Generation, Berlin, Springer, pp. 329-368; and the references cited therein.

[38] Grgur BN, Markovic NM, Ross, PN (1999) The electro-oxidation of $\mathrm{H}_{2}$ and $\mathrm{H}_{2} / \mathrm{CO}$ mixtures on carbon-supported $\mathrm{Pt}_{\mathrm{x}} \mathrm{Mo}_{\mathrm{y}}$ alloy catalysts. J Electrochem Soc 146:1613-1619

[39] Samjeske G, Wang H, Löffler T, Baltruschat H (2002) CO and methanol oxidation at Ptelectrodes modified by Mo. Electrochim Acta 47:3681-3692

[40] Guillén-Villafuerte O, García G, Rodríguez JL, Pastor E, Guil-López R, Nieto E, Fierro JLG (2013) Preliminary studies of the electrochemical performance of $\mathrm{Pt} / \mathrm{X} @ \mathrm{MoO}_{3} / \mathrm{C}\left(\mathrm{X}=\mathrm{Mo}_{2} \mathrm{C}\right.$, $\mathrm{MoO}_{2}, \mathrm{Mo}^{0}$ ) catalysts for the anode of a DMFC: Influence of the Pt loading and Mo-phase. Int J Hydrogen Energy 38:7811-7821

[41] Hu JE, Liu Z, Eichhorn BW, Jackson GS (2012) CO tolerance of nano-architectured Pt-Mo anode electrocatalysts for PEM fuel cells. Int J Hydrogen Energy 37:11268-11275

[42] Esfahani RAM, Vankova SK, Monteverde Videla AHA, Specchia S (2017) Innovative carbon-free low content $\mathrm{Pt}$ catalyst supported on Mo-doped titanium suboxide $\left(\mathrm{Ti}_{3} \mathrm{O}_{5}-\mathrm{Mo}\right)$ for stable and durable oxygen reduction reaction. Appl Catal B-Environ 201:419-429

[43] Aryanpour M, Hoffmann R, DiSalvo FJ (2009) Tungsten-doped titanium dioxide in the rutile structure: theoretical considerations. Chem Mater 21:1627-1635

[44] Micoud F, Maillard F, Gourgaud A, Chatenet M (2009) Unique CO-tolerance of Pt-WOx materials. Electrochem Commun 11:651-654

[45] Micoud F, Maillard F, Bonnefont A, Job N, Chatenet M (2010) The role of the support in COads monolayer electrooxidation on Pt nanoparticles: $\mathrm{Pt} / \mathrm{WO}_{\mathrm{x}}$ vs. Pt/C. Phys Chem Chem Phys 12:1182-1193 
[46] Jusys Z, Kaiser J, Behm RJ (2001) Electrooxidation of CO and $\mathrm{H}_{2} / \mathrm{CO}$ mixtures on a carbonsupported Pt catalyst-a kinetic and mechanistic study by differential electrochemical mass spectrometry- Phys Chem Chem Phys 3:4650-4660 


\title{
Supplementary material for
}

\section{Effect of Mo incorporation on electrocatalytic performance of Ti-Mo mixed oxide- carbon composite supported Pt electrocatalysts}

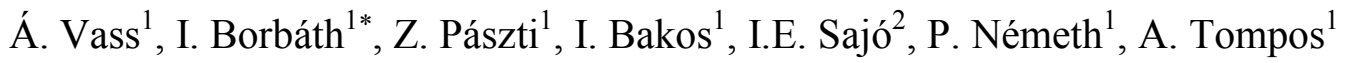 \\ ${ }^{1}$ Institute of Materials and Environmental Chemistry, Research Centre for Natural Sciences, \\ Hungarian Academy of Sciences, H-1117 Budapest, Magyar tudósok körútja 2, Hungary \\ ${ }^{2}$ University of Pécs, Szentágothai Research Centre, Pécs, H-7624, Ifjúság str. 20, Hungary
}

\section{Details of the preparation of the $\mathrm{Ti}_{(1-\mathrm{x})} \mathrm{Mo}_{\mathrm{x}} \mathrm{O}_{2}-\mathrm{C}$ support materials}

The main features of the optimized preparation procedure of $\mathrm{Ti}_{(1-\mathrm{x})} \mathrm{Mo}_{\mathrm{x}} \mathrm{O}_{2}-\mathrm{C}$ composite support materials are briefly summarized in Fig. S1.

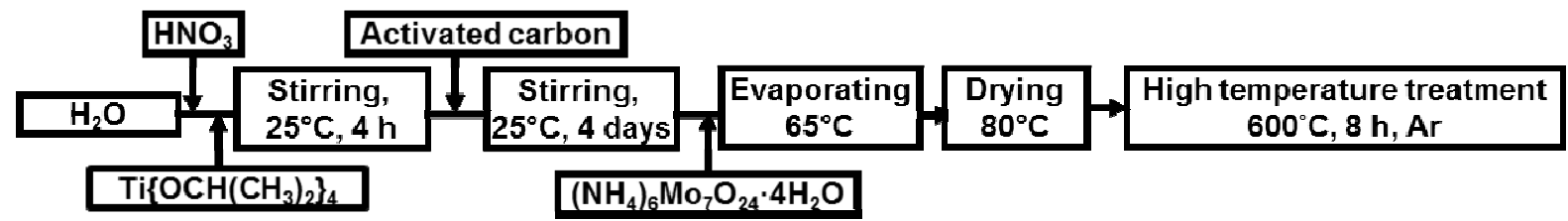

Fig. S1 Flow chart for preparing $\mathrm{Ti}_{(1-\mathrm{x})} \mathrm{Mo}_{\mathrm{x}} \mathrm{O}_{2}-\mathrm{C}$ composite materials by using multistep synthesis route.

As the first step the calculated amount of titanium-isopropoxide was added dropwise to aqueous solution of $\mathrm{HNO}_{3}$, into a round bottom flask with continuous agitation to obtain transparent $\mathrm{TiO}_{2}$ sol. The system was then stirred for 4 hours in order to initiate formation of rutile phase nuclei [S1] and then $250 \mathrm{mg}$ of carbon black (CABOT, Black Pearls 2000) suspended in $5 \mathrm{ml}$ water was added to the mixture. The rutile phase nanoclusters are supposed to precipitate onto the surface of the carbon and the crystal growth takes place within the suitable aging period. In this study the synthesis mixture was stirred for 4 days in order to form $\mathrm{TiO}_{2}$-rutile phase on the surface of the carbon. After the 4 days aging the given amount of the ammonium-molybdate-tetrahydrate was added to the synthesis mixture and was heated up to $65^{\circ} \mathrm{C}$ in order to evaporate the solvent under continuous stirring. Finally, the powder was dried in an oven overnight at $80^{\circ} \mathrm{C}$. The obtained solid has been submitted to heat treatment in order to provoke isovalent cation substitution of $\mathrm{Ti}^{4+}$ in the $\mathrm{TiO}_{2}$-rutile lattice by $\mathrm{Mo}^{4+}$, i.e. incorporation of molybdenum. The heat treatment of the samples was carried out in a vertical quartz tube in a tubular furnace. The samples were heated up to $600^{\circ} \mathrm{C}$ in argon flow and were kept at this temperature for 8 hours, then the system was cooled down to room temperature also in argon flow.

\section{Details of the preparation of the $20 \mathrm{wt} . \% \mathrm{Pt} / \mathrm{Ti}_{(1-x)} \mathrm{Mo}_{x} \mathrm{O}_{2}-\mathrm{C}$ electrocatalysts}

$\mathrm{Ti}_{(1-\mathrm{x})} \mathrm{Mo}_{\mathrm{x}} \mathrm{O}_{2}-\mathrm{C}$ composite materials were loaded with 20 wt.\% Pt via a modified $\mathrm{NaBH}_{4}-$ assisted ethylene-glycol (EG) reduction-precipitation method (see Fig. S2) [S1-S3].

\footnotetext{
* Corresponding author, Tel.: +36 1382 6916, email: borbath.irina@ttk.mta.hu, address: H-1519 Budapest, P.O.Box 286, Hungary (Irina Borbáth)
} 
In all cases $0.643 \mathrm{mmol} \mathrm{H}_{2} \mathrm{PtCl}_{6} \cdot 6 \mathrm{H}_{2} \mathrm{O}$ was solved in $50 \mathrm{ml}$ of ethanol and $200 \mathrm{mg}$ of the samples was suspended in the solution. A solution prepared by mixing of $7.8 \mathrm{mmol} \mathrm{NaBH}_{4}$ and $3.7 \mathrm{ml} \mathrm{EG}$ was added dropwise to the suspension at $65{ }^{\circ} \mathrm{C}$ with continuous stirring. After 3 hours of stirring at $65^{\circ} \mathrm{C}, 15 \mathrm{ml} 0.2 \mathrm{M} \mathrm{HCl}$ was added to the suspension and stirred for an additional 2.5 hours at room temperature in order to deposit the Pt particles onto the support material. The materials were washed three times with $50 \mathrm{ml}$ water and filtered by centrifugation in order to remove the chloride ions and dried at $80^{\circ} \mathrm{C}$ in an oven overnight.

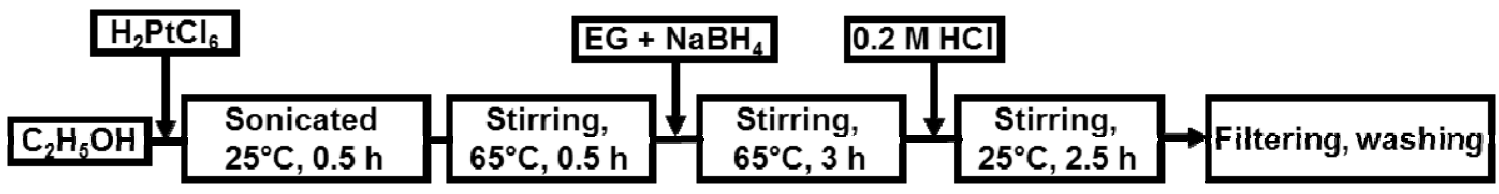

Fig. S2 Flow chart for synthesis of $\mathrm{Pt} / \mathrm{Ti}_{(1-\mathrm{x})} \mathrm{Mo}_{\mathrm{x}} \mathrm{O}_{2}-\mathrm{C}$ electrocatalysts.

\section{Transmission electron microscopy (TEM) investigations}
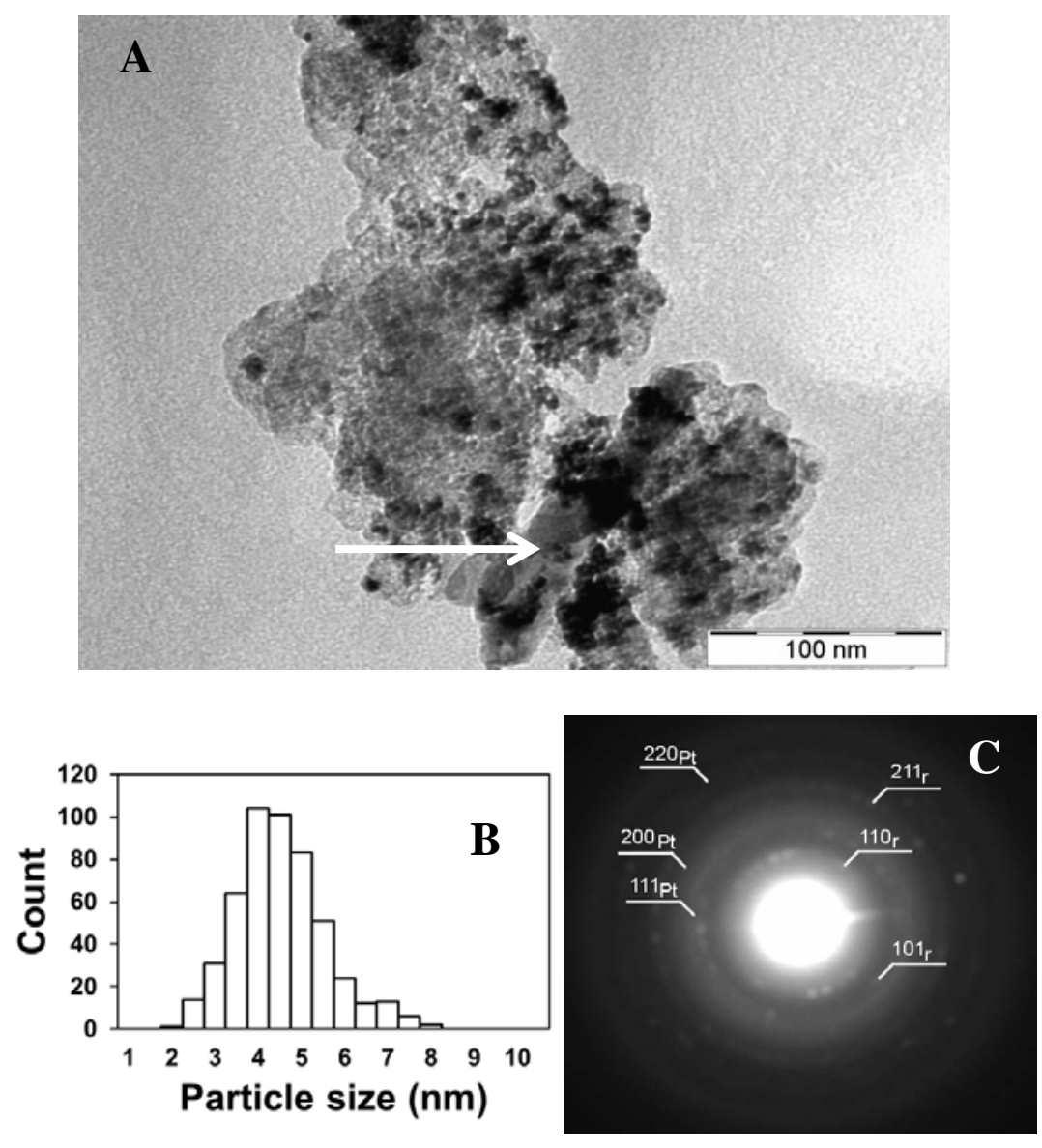

Fig. S3 TEM image (A), histogram of the Pt particle size distribution (B) and electron diffraction pattern $(\mathrm{C})$ of the $\mathrm{Pt} / \mathrm{Ti}_{0.7} \mathrm{Mo}_{0.3} \mathrm{O}_{2}-\mathrm{C}$ electrocatalyst; " $\boldsymbol{r}$ " stands for the Mo-doped rutile phase.

TEM micrograph, electron diffraction pattern and particle size distribution of the $20 \mathrm{wt} . \%$ $\mathrm{Pt} / \mathrm{Ti}_{0.8} \mathrm{Mo}_{0.2} \mathrm{O}_{2}-\mathrm{C}$ catalyst are shown in Figure 2 of the main text. Very similar morphologies were observed for the $\mathrm{Pt} / \mathrm{Ti}_{0.7} \mathrm{Mo}_{0.3} \mathrm{O}_{2}-\mathrm{C}$ and the $\mathrm{Pt} / \mathrm{Ti}_{0.6} \mathrm{Mo}_{0.4} \mathrm{O}_{2}-\mathrm{C}$ catalysts; micrographs, 
electron diffraction patterns and histograms for particle size distribution for these samples are presented in Figs. S3 and S4.

Fig. 2 of the main text and Figs. S3 and S4 reveal the uniform distribution of the $\mathrm{Pt}$ particles with mean particle size of $3.5 \pm 0.9 \mathrm{~nm}, 3.7 \pm 1 \mathrm{~nm}$ and $3.2 \pm 0.8 \mathrm{~nm}$ for samples with $\mathrm{x}=0.2,0.3$ and 0.4 nominal Mo content, respectively. It can be concluded that, within the experimental error, the Mo content has practically no effect on the average particle size and on the particle size distribution, either. The Pt particles are relatively small. The applied reduction-precipitation method leads to fine dispersion and accordingly high active surface area is expected in electrochemical tests. In good accordance with XRD result, electron diffraction patterns revealed the presence of the Mo-containing rutile phase in the samples. Patterns corresponding to the platinum crystallites also appear, although there is considerable overlap between features arising from rutile and fcc Pt (see Fig. $2 \mathrm{C}$ of the main text and Figs. $\mathrm{S} 3 \mathrm{C}$ and $\mathrm{S} 4 \mathrm{C})$.
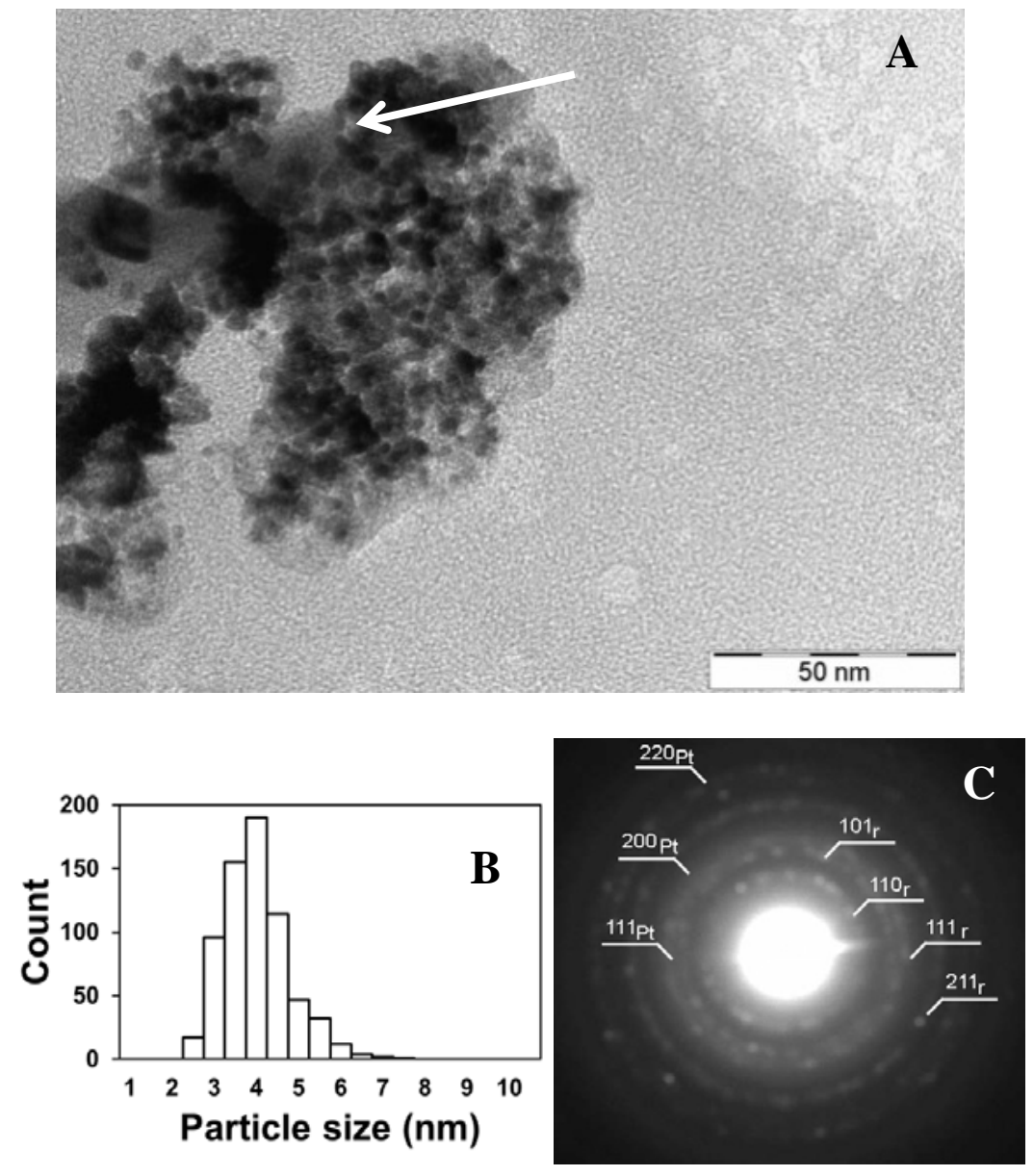

Fig. S4 TEM image (A), histogram of the Pt particle size distribution (B) and electron diffraction pattern $(C)$ of the $\mathrm{Pt} / \mathrm{Ti}_{0.6} \mathrm{Mo}_{0.4} \mathrm{O}_{2}-\mathrm{C}$ electrocatalyst; " $r$ " stands for the Mo-doped rutile phase.

Representative images for average spots of the samples reveal the coexistence of a few large, faceted nanorod-like Mo-doped rutile crystallites (indicated by white arrows) with the carbon-containing composite material. In the micrographs of a composite with $50 \mathrm{wt} \%$ mixed oxide $-50 \mathrm{wt} \%$ active carbon no such crystallites were observed [S1]; their presence is attributed to the increased mixed oxide content of the samples. It can be seen that platinum 
nanoparticles are deposited onto the surface of both the large mixed oxide crystallites and the composite material.

\section{Electrochemical characterization before and after the "pre-leaching” procedure}

It is known that less stable transition metal oxides tend to dissolve under acidic conditions and high potentials. Such leaching and subsequent uncontrolled re-deposition of certain components of the electrocatalyst may be detrimental for the performance of the fuel cell, so stability against initial leaching should be checked. Accordingly, in our work data from the very first CV scans are analyzed and summarized in Fig. S5 for the $\mathrm{Pt} / \mathrm{Ti}_{0.8} \mathrm{Mo}_{0.2} \mathrm{O}_{2^{-}}$ $\mathrm{C}$, the $\mathrm{Pt} / \mathrm{Ti}_{0.6} \mathrm{Mo}_{0.4} \mathrm{O}_{2}-\mathrm{C}$ and the commercial $20 \mathrm{wt} . \% \mathrm{Pt} / \mathrm{C}$ Quintech (C) catalysts.
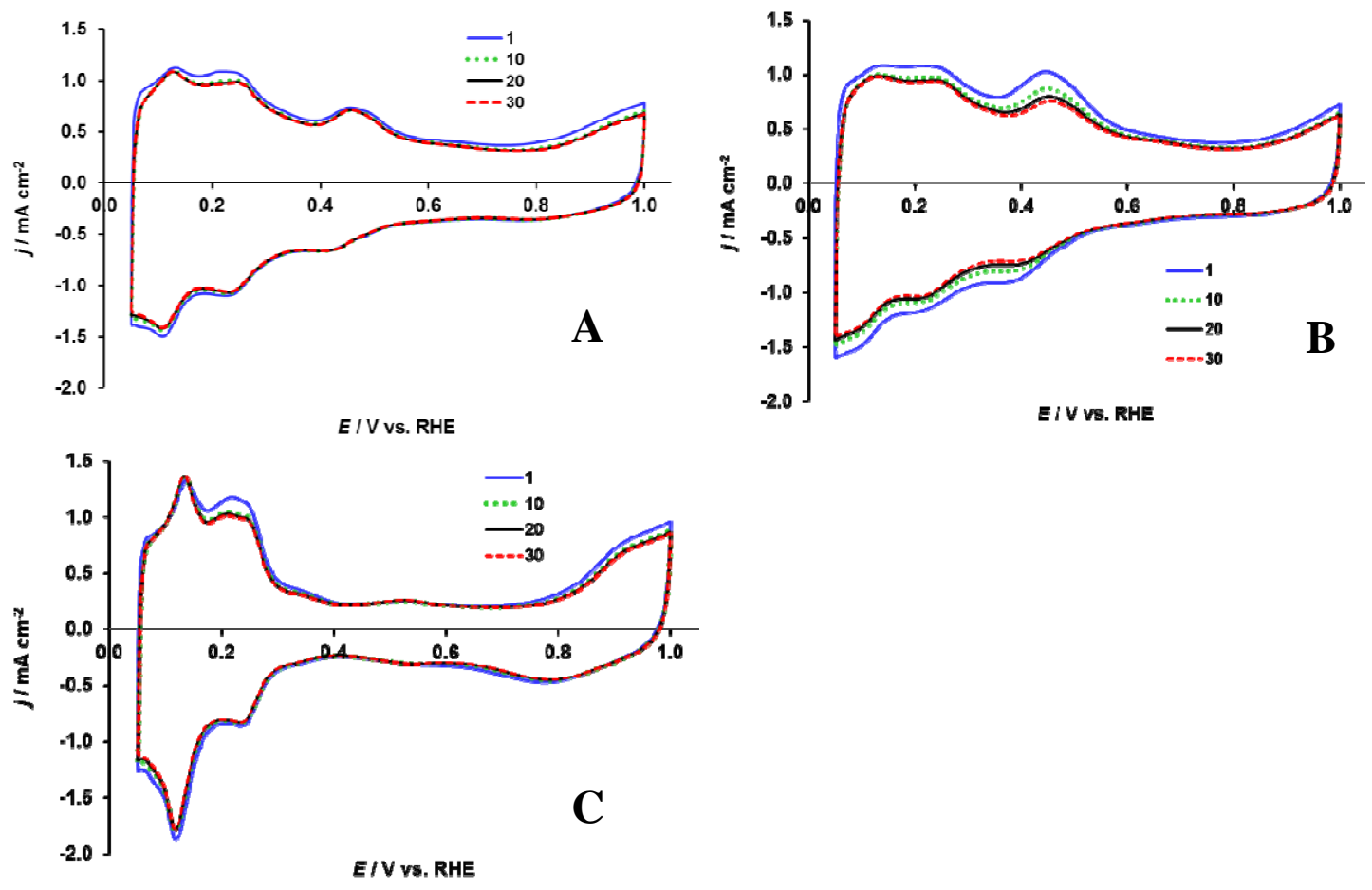

Fig. S5. Cyclic voltammograms of the $\mathrm{Pt} / \mathrm{Ti}_{0.8} \mathrm{Mo}_{0.2} \mathrm{O}_{2}-\mathrm{C}(\mathrm{A})$, the $\mathrm{Pt} / \mathrm{Ti}_{0.6} \mathrm{Mo}_{0.4} \mathrm{O}_{2}-\mathrm{C}$ (B) and the commercial $20 \mathrm{wt} \% \mathrm{Pt} / \mathrm{C}$ Quintech $(\mathrm{C})$ catalysts. CVs recorded in the $1^{\text {st }}$ cycle (blue curve), $10^{\text {th }}$ cycle (dotted green line), $20^{\text {th }}$ (black curve) and $30^{\text {th }}$ cycle (dashed red line) of the "pre-leaching" test in Ar-saturated solution after the $1^{\text {st }} \mathrm{CO}_{\text {ads }}$ stripping measurements.

Recorded in Ar purged $0.5 \mathrm{~mol} \mathrm{dm}{ }^{-3} \mathrm{H}_{2} \mathrm{SO}_{4}$ solution between 50 and $1000 \mathrm{mV}$ potential limits with $100 \mathrm{mV} \mathrm{s}^{-1}$ sweep rate.

In the case of $\mathrm{Pt} / \mathrm{Ti}_{0.8} \mathrm{Mo}_{0.2} \mathrm{O}_{2}-\mathrm{C}$ relatively small changes can be seen during the first $30 \mathrm{CV}$ scans. The substantial changes of the voltammograms of $\mathrm{Pt} / \mathrm{Ti}_{0.6} \mathrm{Mo}_{0.4} \mathrm{O}_{2}-\mathrm{C}$ can be explained by dissolution or rearrangement of the non-incorporated Mo species during the first cycles. The results of our work demonstrate that these initial changes are more expressed on the samples containing the higher amount of non-incorporated Mo species, thus we can expect better leaching properties from catalysts with less non-incorporated Mo-oxide (Fig. S5.A).

In addition, it may be noted that the air exposed catalyst surface may be covered by carbonaceous contaminants or may be heavily oxidized, so its properties are clearly different from the one formed after some cyclic potential scans. In fact, in order to reach a quasi-stable steady state of the surface, a cleaning or conditioning stage consisting of a certain number of $\mathrm{CV}$ scans is routinely applied prior to collection of electrochemical data. Indeed, even in the 
case of the commercial $\mathrm{Pt} / \mathrm{C}$ sample a few $\mathrm{CV}$ cycles are needed for stabilization of the surface conditions.

\section{References}

[S1] Gubán D, Borbáth I, Pászti Z, Sajó IE, Drotár E, Hegedűs M, Tompos A. (2015) Preparation and characterization of novel $\mathrm{Ti}_{0.7} \mathrm{~W}_{0.3} \mathrm{O}_{2}-\mathrm{C}$ composite materials for Ptbased anode electrocatalysts with enhanced $\mathrm{CO}$ tolerance. Appl Catal B-Environ 174:455-470

[S2] Gubán D, Pászti Z, Borbáth I, Bakos I, Drotár E, Sajó IE, Tompos A. (2016) Design and preparation of CO tolerant anode electrocatalysts for PEM fuel cells. Period PolytechChem 60:29-39

[S3] Kim P, Joo JB, Kim W, Kim J, Song IK, Yi, J. (2006) $\mathrm{NaBH}_{4}$-assisted ethylene glycol reduction for preparation of carbon-supported Pt catalyst for methanol electro-oxidation. J Power Sources 160: 987-990 